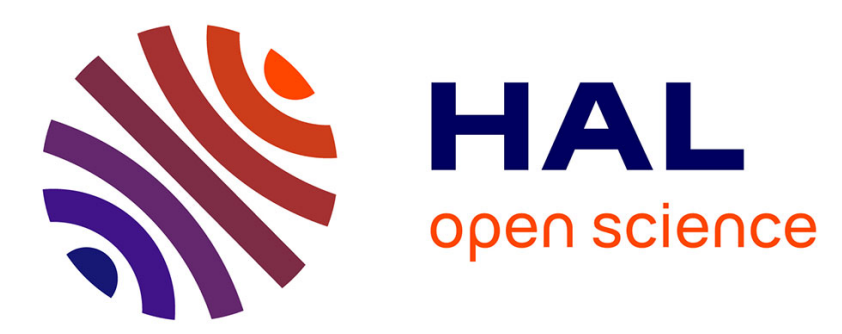

\title{
Comparison of nitrogen monoxide emissions from several African tropical ecosystems and influence of season and fire
}

\author{
Dominique Serça, Robert Delmas, Xavier Le Roux, Dab Parsons, M. Scholes, \\ Luc Abbadie, R. Lensi, Ophélie Ronce, L. Labroue
}

\section{To cite this version:}

Dominique Serça, Robert Delmas, Xavier Le Roux, Dab Parsons, M. Scholes, et al.. Comparison of nitrogen monoxide emissions from several African tropical ecosystems and influence of season and fire. Global Biogeochemical Cycles, 1998, 12 (4), pp.637-651. 10.1029/98GB02737 . halsde-00352350

\section{HAL Id: halsde-00352350 \\ https://hal.science/halsde-00352350}

Submitted on 25 Jan 2021

HAL is a multi-disciplinary open access archive for the deposit and dissemination of scientific research documents, whether they are published or not. The documents may come from teaching and research institutions in France or abroad, or from public or private research centers.
L'archive ouverte pluridisciplinaire HAL, est destinée au dépôt et à la diffusion de documents scientifiques de niveau recherche, publiés ou non, émanant des établissements d'enseignement et de recherche français ou étrangers, des laboratoires publics ou privés. 


\title{
Comparison of nitrogen monoxide emissions from several African tropical ecosystems and influence of season and fire
}

\author{
D. Serça ${ }^{1}$, R. Delmas ${ }^{1}$, X. Le Roux ${ }^{2.3}$, D.A.B. Parsons ${ }^{4}$, M.C. Scholes ${ }^{5}$, L. Abbadie ${ }^{2}$, \\ R. Lensi ${ }^{6}$, O. Ronce ${ }^{2}$, and L. Labroue ${ }^{7}$
}

\begin{abstract}
NO emission rates from soils were measured for twelve major African ecosystems in four countries (Congo, Niger, Ivory Coast, and South Africa) and within four major phytogeographic domains: the Guineo-Congolese, Guinean, Sahelian, and Zambezian domains. Measurements were performed during wet and/or dry seasons. All the measurements were made with the same dynamic chamber device, which allowed true comparisons to be made. This study showed that emission rates strongly differed between ecosystems and exhibited a marked temporal variability. Ecosystem effect was highly significant during both the dry and wet seasons. Emission rates were low ( $\left.<0.6 \mathrm{ng} \mathrm{NO}-\mathrm{N} \mathrm{m}^{-2} \mathrm{~s}^{-1}\right)$ in Hyparrhenia and Loudetia savannas of the Guinean or Guineo-Congolese domains. Intermediate NO fluxes were obtained in rain forest and gallery forest ecosystems, in a broad-leafed savanna and in a seasonally wetted grassland (sandy soil) of the Zambezian domain, and in a dry fallow savanna of the Sahelian domain. Emission rates were maximum ( $>7 \mathrm{ng} \mathrm{NO}-\mathrm{N} \mathrm{m}^{-2} \mathrm{~s}^{-1}$ ) in a seasonally wetted grassland (site 2) and in particular sites subjected to various disturbances, for example soil fauna activity (termite mounds) or past human disturbance (Acacia patches-settlement site). Microbial activity potentials (i.e., carbon mineralization, nitrification, denitrification, and total net $\mathrm{N}$ mineralization) were determined for most of the soils where NO fluxes were measured. In some sites, these potential activities were useful to identify the major processes controlling NO emission rates.

Denitrification potential was very low and could not explain substantial NO fluxes from broadand fine-leafed savannas and Hyperthelia savannas of the Zambezian domain. Very low potentials of both nitrification and denitrification could be related to the low NO fluxes for the three Guinean savanna sites studied. NO fluxes were significantly higher during the wet season than the dry season in both savanna and forest ecosystems. Emission rates in savanna ecosystems were significantly increased within a few hours after fire. The measurements presented here provide a unique, consistent database which can be used to further analyze the processes involved in the spatial and temporal variations of NO emissions.
\end{abstract}

\section{Introduction}

It is recognized that tropospheric ozone production depends on the presence of reactive nitrogen oxides $\left(\mathrm{NO}_{\mathrm{x}}\right.$, i.e., $\mathrm{NO}+$ $\mathrm{NO}_{2}$ ) [Chameides and Walker, 1973; Crutzen, 1973; Fishman et al., 1979, 1985; Logan et al., 1981; Cros et al., 1987; Liu et al.,

\footnotetext{
${ }^{1}$ Laboratoire d'Aérologie - OMP, UMR 5560, Toulouse, France.

${ }^{2}$ Laboratoire d'Ecologie ENS, URA 258, Paris, France.

3 Now at Unité associèe Bioclimatologie-PIAF, Clermont-Ferrand. France.

${ }^{4}$ Division of Forest Science and Technology, CSIR, Pretoria, South Africa.

'Department of Botany, University of the Witwatersrand, Johannesburg, South Africa.

${ }^{6}$ Laboratoire d'Ecologie Microbienne des Sols, UMR 5557, Villeurbanne, France.

${ }^{7}$ Centre d'Ecologie des Systèmes Aquatiques Continentaux, UMR 5576, Toulouse, France.
}

Copyright 1998 by the American Geophysical Union.

Paper number 98GB02737.

0886-6236/98/98GB-02737\$12.00
1987]. Nitrogen oxides also regulate the production of other photochemical oxidants such as $\mathrm{OH}$ radicals and peroxyacetyl nitrates. Furthermore, they have an indirect influence on the quantity and distribution of reactive gaseous compounds of carbon, halogens, and sulfur in the troposphere [Crutzen, 1983] and contribute to acid deposition as nitric acid [Galloway and Likens, 1981; Lacaux et al., 1992]. Among the sources of nitrogen oxides, the emission of nitrogen monoxide, NO, is a particularly important one. NO may be emitted either during anthropogenic or natural biogenic processes [Delmas et al., soil NO emission rates is $21 \mathrm{Tg} \mathrm{N}$ year ${ }^{-1}$. This is in the same order of magnitude as emissions from fossil fuel combustion [Davidson and Kingerlee, 1997].

The factors influencing the quantity and distribution of NO in the tropical troposphere have been identified as particularly important in global atmospheric chemistry [Crutzen, 1987; Mc Elroy and Wofsy, 1986]. Thus it is interesting to study the distribution and intensity of NO sources in the tropics. NO emissions and biomass burning in Africa are clearly linked [Andreae, 1991; Delmas et al., 1991; Fishman et al., 1991]. However, tropical atmospheric chemistry is highly dependent on other local processes, including soil NO emissions [Logan et al., 
1981; Kley et al., 1981; Noxon, 1981, 1983]. In addition, NO is short-lived and relatively scarce in the atmosphere of the intertropical zone; this led to our decision to examine NO emissions from tropical soils.

Tropical forests and savannas may be major sources of NO [Johansson et al., 1988; Johansson and Sanhueza, 1988; Kaplan et al., 1988; Bakwin et al., 1990; Davidson et al., 1991; Rondon et al., 1993; Cardenas et al., 1994; Keller and Reiners, 1994; Neff et al., 1995; Poth et al., 1995]. However, the vast majority of existing data have been collected in Central and South American ecosystems. In contrast, only few data exist on NO emissions from African ecosystems [Delmas and Servant, 1987; Serça et al., 1994; Levine et al., 1996; Parsons et al., 1996; Meixner et al., 1997; Scholes et al., 1997]. African savannas and forests lie between $20^{\circ}$ North and $30^{\circ}$ South. They are of particular interest as they are increasingly subjected to fire [ $\mathrm{HaO}$ et al., 1990] and land use change as a consequence of demographic expansion.

The mechanisms controlling NO production from soils have been studied by numerous authors [Lipschultz et al., 1981; Anderson and Levine, 1987; Conrad, 1990]. Nitric oxide may be produced during the first stage of nitrification (ammonium oxidation) and during denitrification [Firestone and Davidson, 1989]. In either case, any $\mathrm{HNO}_{2}$ formed is unstable in acidic environments where organic matter or ferrous iron are present. Chemodenitrification may therefore take place. According to Van Cleemput and Baert [1984] and Blackmer and Cerrato [1986], this process probably only represents a small fraction of the NO being produced in most environments. However, more recent studies [Veldkamp and Keller, 1997] consider this phenomenon as non-negligible, even in globally non acidic soil. Nitrification and denitrification processes are influenced by soil characteristics such as water content, gas diffusivity, acidity, temperature, and inorganic nitrogen amount [Slemr and Seiler, 1984; Rondon et al., 1993; Dovidson and Schimel, 1995], as well as other edaphic, climatic, and vegetative factors [Galbally, 1985]. Owing to the great variability of these characteristics, spatial and temporal variability of nitrogen cycling processes (i.e., nitrification and denitrification) and concurrent NO emissions is high [Schimel et al., 1988; Matson et al., 1990; Ambus and Christensen, 1994; Davidson and Kingerlee, 1997; Thornton et al., 1997]. Davidson and Kingerlee [1997] presented a global inventory of field measurements of nitric oxide fluxes reported in over 60 published papers. In these articles, over 100 annual estimates of NO emissions were made for various types of ecosystems. In spite of careful biome stratification, the variation of NO fluxes within the biomes is large. The uncertainty associated with the current best estimate $\left(21 \mathrm{Tg} \mathrm{N}\right.$ year $\left.^{-1}\right)$ remains high $( \pm 20-50 \%)$. A more sophisticated ecosystem stratification, linked to the soil physicochemical and microbial properties, is needed to reduce this uncertainty. However, measurements of NO fluxes associated with key soil characteristics and microbial activities are not available for all terrestrial biomes. Thus it has not yet been possible to assess the potential range of $\mathrm{NO}$ emissions for these ecosystems or to describe systematic relationships between fluxes and soil physicochemical parameters or microbial activities. This lack of knowledge is a major deterrent for (1) extrapolation from instantaneous measurements to seasonal estimates, (2) reliable extrapolation of emission measurements from the local scale (i.e.,. point measurements) to the ecosystem, regional, and global scales, and (3) prediction of emission changes in relation to climatic or anthropogenic disturbances [Schimel et al., 1988; Matson et al., 1989].

The results presented here were obtained between June 1991 and March 1993 for six supersites (see section 2.1.1.) located in four different African countries. Measurements were carried out in 12 forest and savanna ecosystems during the dry and/or wet seasons. A biogenically and an anthropogenically disturbed site (see description section 2.1.3) were also studied for two ecosystems. All measurements were made using the same equipment and methodology based on the dynamic chamber technique. This method is the most suitable for measuring NO fluxes within a given ecosystem or landscape and correlating these with studies of the processes controlling emissions [Livingston and Hutchinson, 1995]. The objective of this work was to provide a database of nitrogen monoxide emissions from major African ecosystems. The methodology used was not designed to study the small-scale variability of NO fluxes in relation to the variation in soil/microsite/nutrient cycling existing within a given ecosystem, even meters apart [Ambus and Christensen, 1994]. Rather, this work addressed the variability of NO fluxes between the different ecosystems studied. Thus our database was used to perform a statistical analysis between the different ecosystems and the temporal variability of NO emissions. The effects of ecosystem, season, and fire occurrence on NO emissions have been analyzed. For most of the ecosystems studied, complementary measurements of potential microbial activities (providing indices for total heterotrophic microbial activity, nitrification, and denitrification) were performed for soils where fluxes were measured. Mean soil biological activities characterizing the different ecosystems were correlated with mean NO emissions from the soil of these ecosystems in an attempt to understand the variability of NO emission rates between ecosystems. The importance of taking into account the marked interecosystem and temporal variability of NO fluxes in the African tropical zone is discussed.

\section{Experimental Methods}

\subsection{Design of NO Flux Sampling}

2.1.1. Phytogeographic domains and ecosystems studied. The classification of phytogeographic domains in Africa is based on the contrast existing between the dry and the wet tropics [Menaut, 1983]. Tropical Africa is divided into two regions: (1) the Guineo-Congolese region, characterized by a forest landscape and a rain forest climax, and (2) the SudanoZambezian region, dominated by grassland communities, originating from a dry forest climax. Each of these two regions is divided into a number of domains (Figure 1). Fluxes were measured in six supersites chosen to represent major phytogeographic domains found in Africa: the Guineo-Congolese domain (Mayombe wet evergreen forest, Congo), the Guinean domain (Lamto humid savannas and gallery forests mosaic, Ivory Coast), the Sahelian domain (Banizoumbou dry savannas, Niger), the Guineo-Congolese/Zambezian regional transitional domain (humid savannas of the Teke plateaus, Congo), and the Zambezian domain (mesic savannas of the Nylsvley Reserve and 


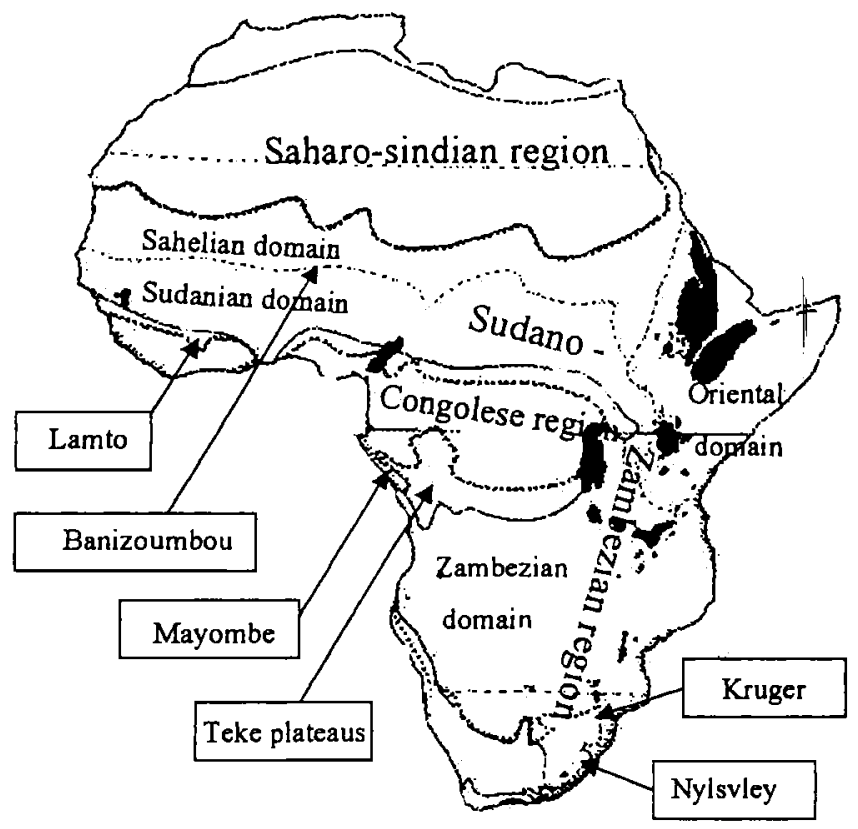

Figure 1. Map of the major phytogeographic region and domains in Africa and location of the six supersites (adapted from Menaut [1983]).

Kruger Park, South Africa) (Figure 1). The main characteristics of the six domains corresponding to the six supersites are presented in Table 1. Each supersite encompassed an area covering $1-10 \mathrm{~km}^{2}$. However, they are representative of extensive areas of Africa. The major ecosystems encountered at this scale (from one in the rain forest supersite up to five in the forest-savanna mosaic encountered within the Lamto supersite in Ivory Coast) were sampled. The main characteristics of the six supersites are presented in Table 2.

The Congo measurements were taken in the Mayombe forest [Serça et al., 1994] and in the Teke plateaus savanna north of Brazzaville. This savanna is not used for agriculture or stockfarming but is bumed annually. The Niger measurements were taken in the Niamey region on the Hydrologic Atmospheric Pilot Experiment in the Sahel (HAPEX-SAHEL) supersite. The location, near the village of Banizoumbou, is fallow and is used for cattle grazing. The Ivory Coast measurements were made at the Lamto Tropical Reserve. This Reserve has not been subjected to agriculture practices for at least the last 40 years. The landscape is a forest-savanna mosaic. Five ecosystems were sampled: gallery forest, Loudetia, Hyparrhenia, and transition (mixed Loudetia and Hyparrhenia) savannas, along with a secondary forest derived from a savanna protected from fire for 35 years. The Kruger National Park is located in the savanna biome of the Mpumalanga Province of South Africa. Emission data were collected during the Southem African FireAtmosphere Research Initiative (SAFARI) experiment in October 1992. The Nylsvley Reserve is located in the South African savanna biome (Zambezian domain) [Werger and Coetzee, 1978]. The savanna vegetation is composed of a mosaic of broad-leafed and fine-leafed savannas with Burkea africana and Acacia tortillis dominating the woody component in the former and latter ecosystems, respectively [Coetzee et al., 1976]. In addition, measurements were also taken on a seasonally wetted grassland. In this ecosystem, two distinct sites were selected based on their very different soil texture: a sandy soil site ( $85 \%$ sand, referred to later as site 1$)$ and a clay soil site $(85 \%$ clay + silt, referred to later as site 2$)$. A total of 12 ecosystems were studied as detailed in Table 3.

2.1.2 Effects of season and fire frequency. The effect of season was studied in two supersites. NO emissions were measured during both the dry and wet seasons in the Mayombe forest, and in the Lamto Tropical Reserve. The location of the chambers frames was marked, and the measurements in the dry and in the wet season were made, as much as possible, on the exact same spot. The effect of fire was studied in the Kruger Park and in the Lamto supersites. In this latter supersite, controlled savanna fires occur each year in January and consume much of the grass layer. In the Kruger Park, measurements were taken in the long-term fire experiment plots laid out in the

Table 1. Main Characteristics of the Major African Phytogeographic Domains Studied

\begin{tabular}{|c|c|c|c|}
\hline Phytogeographic Domain & Characteristics & $\begin{array}{l}\text { Phytogeographic Zone } \\
\text { (Predominant species) }\end{array}$ & $\begin{array}{l}\text { Supersite } \\
\text { (Country) }\end{array}$ \\
\hline Guinean & $\begin{array}{l}P>1000 \mathrm{~mm} \\
\text { dry season }<2 \text { months }\end{array}$ & humid savanna and gallery forest mosaic & Lamto \\
\hline $\begin{array}{l}\text { Guineo-Congolese/Zambezian } \\
\text { regional transitional }\end{array}$ & $\begin{array}{l}P>1500 \mathrm{~mm} \\
\text { dry season: } 2-4 \text { months }\end{array}$ & $\begin{array}{l}\text { humid savanna } \\
\text { (Hyparrhenia diplandra) }\end{array}$ & $\begin{array}{l}\text { Teke plateaus } \\
\text { (Congo) }\end{array}$ \\
\hline Guineo-Congolese & $\begin{array}{l}P>1200 \mathrm{~mm} \\
\text { dry season }<2 \text { months }\end{array}$ & $\begin{array}{l}\text { rain forest } \\
\text { (Gilbertiodendron dewevrei, Piptadenio- } \\
\text { Celtidetalia) }\end{array}$ & $\begin{array}{l}\text { Mayombe forest } \\
\text { (Congo) }\end{array}$ \\
\hline Sahelian & $\begin{array}{l}P<600 \mathrm{~mm} \\
\text { dry season }>8 \text { months }\end{array}$ & $\begin{array}{l}\text { dry savanna } \\
\text { Cenchrus sp., Aristida sp., Guiera senegalensis) }\end{array}$ & $\begin{array}{l}\text { Banizoumbou } \\
\text { (Niger) }\end{array}$ \\
\hline Zambezian & $\begin{array}{l}500<\mathrm{P}<1400 \mathrm{~mm} \\
\text { dry season }<6 \text { months }\end{array}$ & $\begin{array}{l}\text { mesic savanna } \\
\text { (Hyperthelia dissoluta, Terminalia sericea) }\end{array}$ & $\begin{array}{l}\text { Kruger Park } \\
\text { (South Africa) }\end{array}$ \\
\hline Zambezian & $\begin{array}{l}500<P<1400 \mathrm{~mm} \\
\text { dry season }<6 \text { months }\end{array}$ & $\begin{array}{l}\text { mesic savanna } \\
\text { Burkea africana, Erasgrostis pallens) } \\
\text { seasonally wetted grassland (site 1) } \\
\text { (Oryza longistaminata leersia, Hetandra) } \\
\text { seasonally wetted grassland (site 2) } \\
\text { (Themeda triandra) }\end{array}$ & $\begin{array}{l}\text { Nylsvley Reserve } \\
\text { (South Africa) }\end{array}$ \\
\hline
\end{tabular}




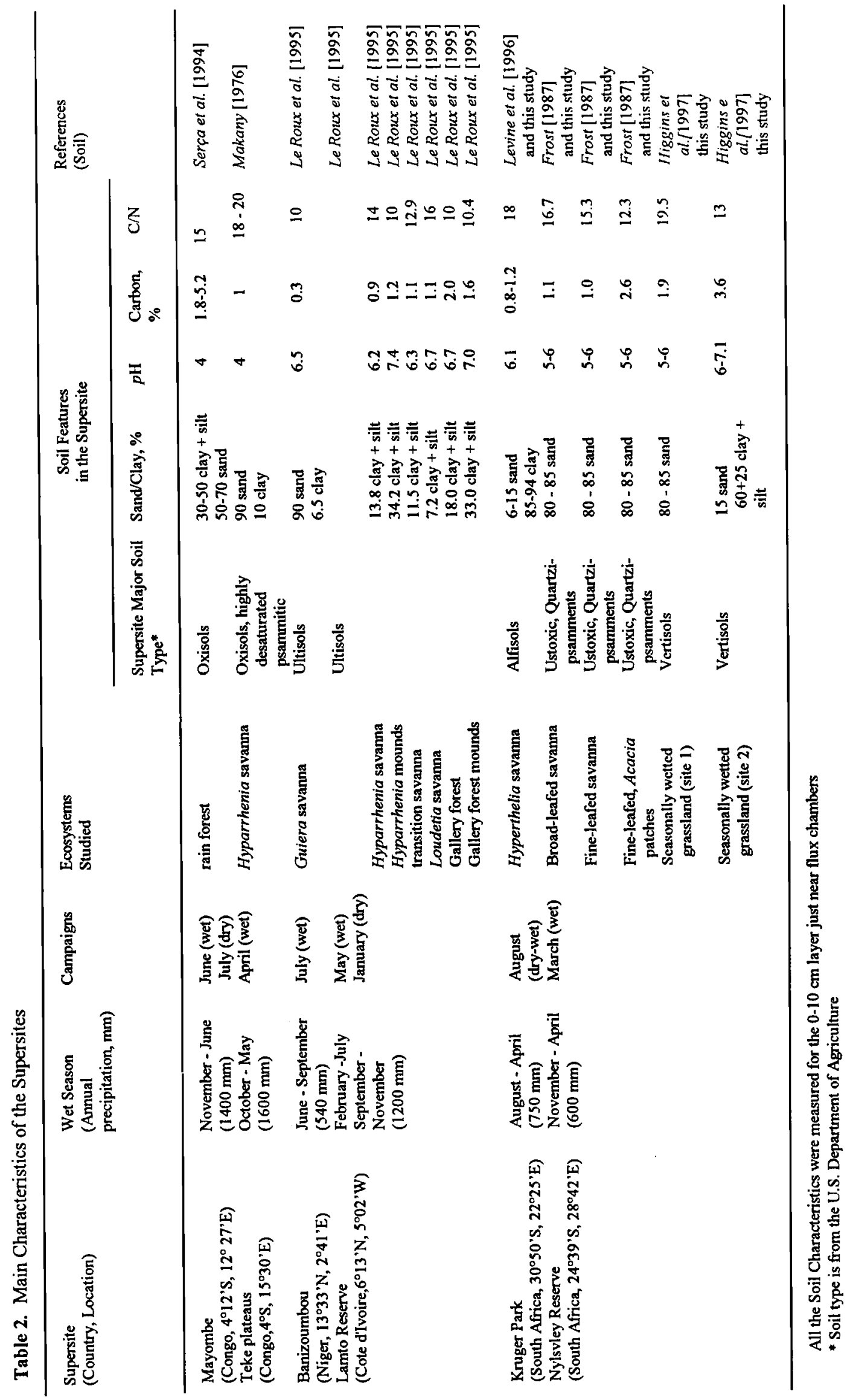


Table 3. Mean Biogenic Emissions of Nitrogen Monoxide From the 12 Ecosystems Studied

\begin{tabular}{|c|c|c|c|c|c|c|}
\hline Ecosystems & $\begin{array}{l}\text { Phytogeographic Zone } \\
\text { (Location, Country) }\end{array}$ & Season & $\begin{array}{c}\text { Mean Flux } \\
\text { ng NO-N } \\
\mathrm{m}^{-2} \mathrm{~s}^{-1} \\
\end{array}$ & $\begin{array}{l}95 \% \text { Confi- } \\
\text { dence Limits }\end{array}$ & $N$ & Reference \\
\hline \multicolumn{7}{|c|}{ Forest Ecosystems } \\
\hline F1a, rain forest & $\begin{array}{l}\text { Guineo-Congolese } \\
\text { (Mayombe, Congo) }\end{array}$ & dry & 1.54 & 1.23 & 4 & Serça et al. [1994] \\
\hline F1b, rain forest & $\begin{array}{l}\text { Guineo-Congolese } \\
\text { (Mayombe, Congo) }\end{array}$ & wet & 4.41 & 1.87 & 11 & Serça et al. [1994] \\
\hline F2a, gallery forest & $\begin{array}{l}\text { Guinean } \\
\text { (Lamto Reserve, Ivory coast) }\end{array}$ & wet & 1.47 & 0.67 & 9 & Le Roux et al. [1995] \\
\hline F2b, gallery forest termite mound & $\begin{array}{l}\text { Guinean } \\
\text { (Lamto Reserve, Ivory coast) }\end{array}$ & wet & 7.17 & 1.21 & 5 & Le Roux et al. [1995] \\
\hline $\begin{array}{l}\text { F3, secondary forest derived from } \\
\text { protected savanna }\end{array}$ & $\begin{array}{l}\text { Guinean } \\
\text { (Lamto Reserve, Ivory coast) }\end{array}$ & dry & 4.95 & 1.97 & 14 & this study \\
\hline \multicolumn{7}{|c|}{ Savanna Ecosystems } \\
\hline S1, Hyparrhenia savanna & $\begin{array}{l}\text { Guinean-Congolese/Zambezian } \\
\text { transitional region } \\
\text { (Teke Plateaus Congo) }\end{array}$ & wet & 0.06 & 0.03 & 3 & this study \\
\hline S2a, Hyparrhenia savanna before fire & $\begin{array}{l}\text { Guinean } \\
\text { (Lamto Reserve, Ivory coast) }\end{array}$ & dry & 0.11 & 0.03 & 9 & this study \\
\hline $\mathbf{S} 2 \mathrm{~b}$, Hyparrhenia savanna after fire & $\begin{array}{l}\text { Guinean } \\
\text { (Lamto Reserve, Ivory coast) }\end{array}$ & dry & 0.65 & 0.35 & 9 & this study \\
\hline S2c, Hyparrhenia savanna & $\begin{array}{l}\text { Guinean } \\
\text { (Lamto Reserve, Ivory coast) }\end{array}$ & wet & 0.56 & 0.21 & 9 & Le Roux et al. [1995] \\
\hline $\begin{array}{l}\text { S2d, Hyparrhenia savanna termite } \\
\text { mounds }\end{array}$ & $\begin{array}{l}\text { Guinean } \\
\text { (Lamto Reserve, Ivory coast) }\end{array}$ & wet & 1.32 & 0.38 & 5 & Le Roux et al. [1995] \\
\hline S3, transition savanna & $\begin{array}{l}\text { Guinean } \\
\text { (Lamto Reserve, Ivory coast) }\end{array}$ & wet & 0.39 & 0.13 & 4 & Le Roux et al. [1995] \\
\hline S4, Loudetia savanna & $\begin{array}{l}\text { Guinean } \\
\text { (Lamto Reserve, Ivory coast) }\end{array}$ & wet & 0.28 & 0.08 & 5 & Le Roux et al. [1995] \\
\hline S5a, Hyperthelia savanna before fire & $\begin{array}{l}\text { Zambezian } \\
\text { (Kruger Park, South Africa) }\end{array}$ & dry & 3.44 & 1.75 & 8 & this study \\
\hline SSb, Hyperthelia savanna after fire & $\begin{array}{l}\text { Zambezian } \\
\text { (Kruger Park, South Africa) }\end{array}$ & dry & 11.32 & 6.53 & 6 & this study \\
\hline S6, Broad-leafed savanna & $\begin{array}{l}\text { Zambezian } \\
\text { (Kruger Park, South Africa) }\end{array}$ & wet & 4.01 & 1.30 & 10 & this study \\
\hline S7a, Fine-leafed savanna & $\begin{array}{l}\text { Zambezian } \\
\text { (Nylsvley Reserve, South Africa) }\end{array}$ & wet & 3.92 & 1.07 & 9 & this study \\
\hline $\begin{array}{l}\text { S7b, Fine-leafed savanna Acacia } \\
\text { patches-settlement site }\end{array}$ & $\begin{array}{l}\text { Zambezian } \\
\text { (Nylsvley Reserve, South Africa) }\end{array}$ & wet & 13.25 & 5.89 & 7 & this study \\
\hline $\begin{array}{l}\text { S8a, Seasonally wetted grassland } \\
\text { (sandy soil, site 1) }\end{array}$ & $\begin{array}{l}\text { Zambezian } \\
\text { (Nylsviey Reserve, South Africa) }\end{array}$ & wet & 2.60 & 0.50 & 8 & this study \\
\hline $\begin{array}{l}\text { S8b, Seasonally wetted grassland (clay } \\
\text { soil, site 2) }\end{array}$ & $\begin{array}{l}\text { Zambezian } \\
\text { (Nylsvley Reserve, South Africa) }\end{array}$ & wet & 8.12 & 3.28 & 9 & this study \\
\hline S9, Guiera savanna & $\begin{array}{l}\text { Sahelian } \\
\text { (Banizoumbou, Niger) }\end{array}$ & wet & 6.09 & 2.64 & 7 & Le Roux et al. [1995] \\
\hline
\end{tabular}

$N$ refers to individual chamber measurements

vicinity of Pretoriuskop during the last days of the dry season. In both cases, measurements were done before and within 2 hours after the occurrence of fire. Chamber frames were not moved between the prefire and the postfire measurements.

2.1.3. Effects of disturbances. In addition to the 12 ecosystems sampled, NO fluxes were measured in particular sites subjected to various disturbances within a given ecosystem: (1) old termite mounds in gallery forest and Hyparrhenia savanna of the Guinean domain which are subjected to intense soil fauna activity [Abbadie et al., 1992] and (2) Acacia patches, with relatively more nutrient-rich soils which are a consequence of a long-term anthropogenic disturbance. These patches are linked to relics of accumulated dung, charcoal and firewood resulting from the settlement of Middle Iron Age people over 700 years ago [Blackmore et al., 1990].

\subsection{NO Flux Measurements}

A dynamic chamber method using a Luminox LMA3 Scintrex Corp. (C nitrogen oxide analyzer was used to measure NO fluxes. This apparatus detects $\mathrm{NO}_{2}$ by chemiluminescence. The $\mathrm{NO}_{2}$ in the air sample reacts with a solution (Luminole) which emits, after deexcitement, a certain quantity of light that is proportional to the quantity of $\mathrm{NO}_{2}$ reacted. NO may be measured after conversion into $\mathrm{NO}_{2}$ by chromium trioxide $\left(\mathrm{CrO}_{3}\right)$. This analyzer is known to be disturbed by ozone, $\mathrm{HNO}_{3}$, and PANs, but none of these gases are thought to be emitted by the soils on which measurements were made. Comparison experiments with a TECO-14A analyzer (chemiluminescence of $\mathrm{NO}_{\text {with }} \mathrm{O}_{3}$ ) carried out in the Amazon [Bakwin et al., 1990] produced flux values comparable to those calculated from the Luminox data. This 
analyzer is also known to be sensitive to temperature changes and to the batch of Luminole used. Air humidity sensitivity was tested by Williams and Davidson [1993]. The Luminox is slightly affected by water vapor, with a sensitivity decrease of about $7 \%$ for a relative humidity of $50 \%$. The instrument was calibrated before and after each campaign (typically a week) and for each new Luminol(C) batch. The multipoint calibration was checked every day at the experimental site using a field calibration instrument (Environment SA VE 3M®). This instrument provided zero air and calibrated $\mathrm{NO}_{2}$ concentrations from a $\mathrm{NO}_{2}$ permeation tube in the range 20-200 ppbv. The dilution was regulated by a mass flowmeter. NO calibration was performed with the same calibration instrument connected to portable standard cylinders of NO diluted with pure nitrogen that provided an outlet NO mixing ratio in the range 5-50 ppbv. The portable NO cylinder was checked against another NO cylinder in the laboratory after each field campaign. Calibrations were made at room temperature $\left(25^{\circ}-27^{\circ} \mathrm{C}\right)$ to avoid zero drift. $\mathrm{NO}$ and $\mathrm{NO}_{2}$ calibrations were used to check the efficiency of NO to $\mathrm{NO}_{2}$ conversion through the catalytic chromium converter. All together, changes in NO Luminox $\odot$ readings were in the range of $10-12 \%$ between two consecutive calibrations made with the same Luminole batch. These changes were accounted for during the data analyses through corrections of the concentrations supposing a linear drift of the instrument between two consecutive calibrations.

Stainless steel chambers ( $15 \mathrm{~cm}$ height) covering a surface area of $800 \mathrm{~cm}^{2}$ were used for flux measurements. Stainless steel frames were inserted into the ground between 3 and 8 hours before the measurements were made in order to prevent immediate disturbances of air diffusion from soil as well as long-term effects on fluxes [Matson et al., 1990]. A mass balance calculation was applied to the soil-chamber system, and the NO flux rate was computed from the slope of the initial linear increase in NO concentration in the chamber [Davidson et al., 1991; Serça et al., 1994] with the following relationship:

$$
F_{\mathrm{NO}}=(\Delta C / \Delta t)\left(V M_{\mathrm{N}} / A R T\right)
$$

where $F_{\mathrm{NO}}$ is the NO emission flux (ng $\left.\mathrm{N} \mathrm{m}^{-2} \mathrm{~s}^{-1}\right),(\Delta C / \Delta t)$ is the initial rate of increase in NO concentration calculated by linear regression ( $\mathrm{ppb} \mathrm{s}^{-1}$ ), $V$ is the chamber volume (cubic centimeters), $M_{\mathrm{N}}$ is the nitrogen molecular weight (grams), $A$ is the sampling area (square centimeters), $R$ is the gas constant $\left(\mathrm{cm}^{3} \mathrm{~atm} \mathrm{~mol} \mathrm{l}^{-1} \mathrm{~K}^{-1}\right)$, and $T$ is the air temperature in the chamber (Kelvins). Pressure was assumed to be constant throughout the flux measurement and equal to ambient pressure. In order to estimate the magnitude of NO fluxes for each ecosystem, several spatial replicates (i.e., individual flux chamber measurements) were performed per ecosystem. Preliminary results obtained for savanna sites of Lamto (results do not appear here) showed no discernible diurnal trend, implying no dependence of NO fluxes on temperature. Several studies [Kaplan et al., 1988; Johansson et al., 1988; Sanhueza et al., 1990; Davidson et al., 1991; Rondon et al., 1993; Cardenas et al., 1994] showed that the relationship between NO emissions and temperature is generally weak in tropical ecosystems. In contrast, other studies have shown that there was a correlation between temperature and NO fluxes in temperate ecosystems [Anderson and Levine, 1987; Williams et al., 1988; Martin et al., 1997]. There is no commonly agreed explanation to justify this difference in functioning between the two climatic zones. Given the system sensitivity and the uncertainty in the slope estimation, the lowest detectable flux was $0.03 \mathrm{ng}$ NO-N m $\mathrm{m}^{-2} \mathrm{~s}^{-1}$.

\subsection{Measurement of Soil Characteristics}

In each site (ecosystem or disturbed site within a given ecosystem), five soil sample cores were collected just after the flux measurements for one depth $(0-10 \mathrm{~cm})$. The cores were sampled within the frames of some of the chambers or less than $20 \mathrm{~cm}$ away. Soil $\mathrm{pH}$ was measured immediately in a $2: 1$ waterto-soil slurry. The soil samples were immediately airdried and stored. In the laboratory, total carbon was determined by potassium dichromate oxidation and titration of dichromate remaining with ammonium fer II sulfate [Anne, 1945]. Total nitrogen was measured by the Kjeldahl method with Kjeltec Auto 1030 Analyzer (TECATOR) after digestion with sulfuric acid. All the measurements were replicated 3 times from subsamples of each soil core.

\subsection{Measurement of Potential Microbial Activities}

In each site where NO emission rates were determined (except for Congo forest and savanna), several microbial activities were measured in the laboratory on the five soil cores sampled in each site (see section 2.3). The following activities were measured: (1) potential $\mathrm{CO}_{2}$ accumulation as an index of total heterotrophic microbial activity, (2) nitrate accumulation in aerobic conditions as an index of potential net nitrification, and (3) $\mathrm{N}_{2} \mathrm{O}$ production in presence of acetylene and with nonlimiting nitrate added as an index of potential denitrification. Potential microbial activities of the soil samples were measured exactly as detailed by Le Roux et al. [1995]. The methodology is only briefly presented here. Carbon dioxide accumulation was measured using $20 \mathrm{~g}$ of dry soil rehumidified to $80 \%$ of waterholding capacity and incubated under aerobic conditions for 12 days. Nitrate and ammonium accumulation were measured spectrophotometrically after the incubation. Net accumulation values were computed by subtracting ammonium, nitrate, and nitrite contents in soils prior to the incubations. Total nitrogen accumulation is defined as the sum of the net nitrate $\left(\mathrm{NO}_{3}{ }^{\circ}\right)$ and the net ammonium $\left(\mathrm{NH}_{4}^{+}\right)$accumulations. Denitrification potential was measured using $10 \mathrm{~g}$ of rehumidified soil under anaerobic conditions and in the presence of acetylene (90:10 He$\mathrm{C}_{2} \mathrm{H}_{2}$ atmosphere) and with nonlimiting nitrate added (final concentration is $80 \mu \mathrm{g} \mathrm{NO} \mathrm{N}^{-1}$ dry soil). Carbon (electron donor) was not added as in the original method described by Tiedje [1982] because it is interesting to consider endogeneous carbon as a stable parameter driving not only the denitrifying populations but also the expression of denitrifiers. The incubations were carried out for 4 hours, and $\mathrm{N}_{2} \mathrm{O}$ was analyzed by gas chromatography. This led to a detection limit for the denitrification potential of $1 \mathrm{ng} \mathrm{N}_{2} \mathrm{O}-\mathrm{N} \mathrm{g}^{-1}$ dry soil in 4 hours. All the microbial activity measurements were made in three replicates from subsamples of each soil core.

Owing to the sampling design, we did not intend to correlate the individual NO fluxes and individual potential microbial activities using paired analyses. We only analyzed the relationship between the mean soil biological activities characterizing the different ecosystems and the mean NO 


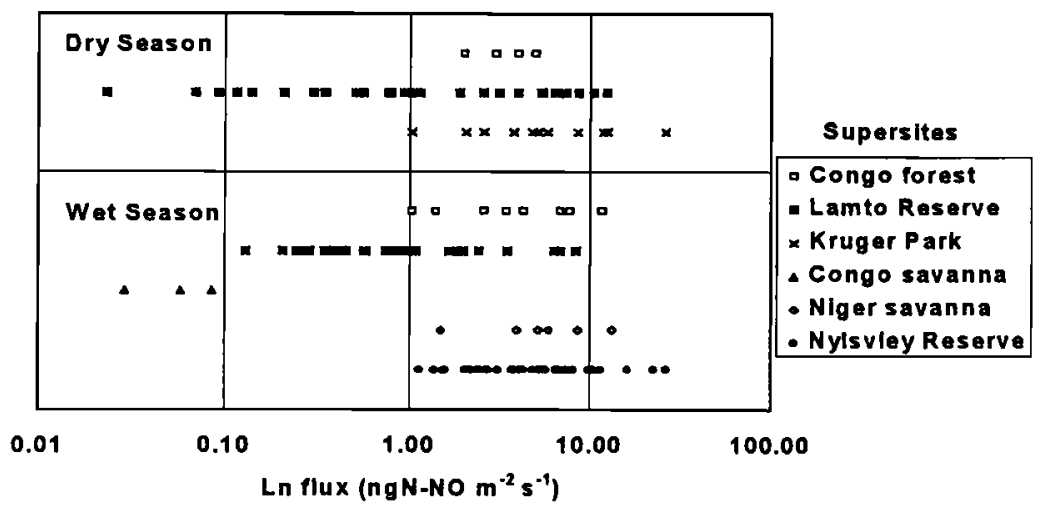

Figure 2. Range of individual NO fluxes (i.e., individual chamber measurements) observed within each supersite during (top) the dry and (bottom) the wet seasons. Note that $X$ axis is in logarithmic scale.

emission rates from the soil of these ecosystems to better understand the variability of NO emission rates between ecosystems.

\subsection{Statistical Analysis}

Analysis of variance was performed in order to test the effects of sites, season and fire on NO fluxes. Statistics applied to the fluxes showed that NO fluxes do not fit a normal distribution but a lognormal distribution. Thus the flux variable was transformed into the natural logarithm for the statistical tests. Scheffe's test and Tukey's test were used to determine if means differed significantly from one another. Site effect was tested both during the wet and the dry seasons. The effects of season or fire occurrence were tested for sites where adequate data were available.

\section{Results}

\subsection{Variability of NO Emission Rates Between Ecosystems}

Individual NO fluxes measured during either the dry or wet seasons are presented in Figure 2. Whatever the season, the variability of NO fluxes was very high within each supersite. For a given supersite, the range of individual emission rates spanned 1 order of magnitude up to 2 orders of magnitude for the Lamto forest/savanna mosaic supersite. Data variability led to standard deviations greater than the mean for each supersite (results not shown).

Mean NO fluxes from each site are presented in Table 3. The spatial variability was weaker at the site scale than at the supersite scale (i.e., standard deviations are smaller than the mean). Site effect on NO fluxes was highly significant during both dry and wet seasons (both $p=0.0001$ ). During the wet season (Figure 3), the lowest emission rates ( $<0.6 \mathrm{ng}^{\mathrm{NO}} \mathrm{N} \mathrm{N} \mathrm{m}^{-2}$ $\mathrm{s}^{-1}$ ) were observed in the Hyparrhenia, transition, and Loudetia savannas of the Guinean or Guineo-Congolese domains. Intermediate NO fluxes were observed in the Congo rain forest and Lamto gallery forest ecosystems, in the sandy soil seasonally wetted grassland and broad-leafed savannas (Zambezian domain), and in dry fallow savanna of the Sahelian domain. Emission rates were highest $\left(>7 \mathrm{ng} \mathrm{NO}-\mathrm{N} \mathrm{m}^{-2} \mathrm{~s}^{-1}\right.$ ) in the seasonally wetted grassland (site 2) of the Nylsvley Reserve and for particular sites subjected to soil fauna activity (termite mounds) or past human disturbance (Acacia patches-settlement site). During the dry season (Figure 4), NO fluxes were low for the Hyparrhenia savanna of the Guinea domain, whereas the Hyperthelia savanna and secondary forest ecosystems exhibited higher emission rates. Intermediate values were found for the rain forest.

\subsection{Season and Fire Effects on NO Emission Rates}

NO fluxes during the both wet and dry seasons were available for two ecosystems (the rain forest and the Lamto Hyparrhenia savanna) (Figure 5). Effects of both site and season were significant at $p=0.0001$, but the interaction effect was not

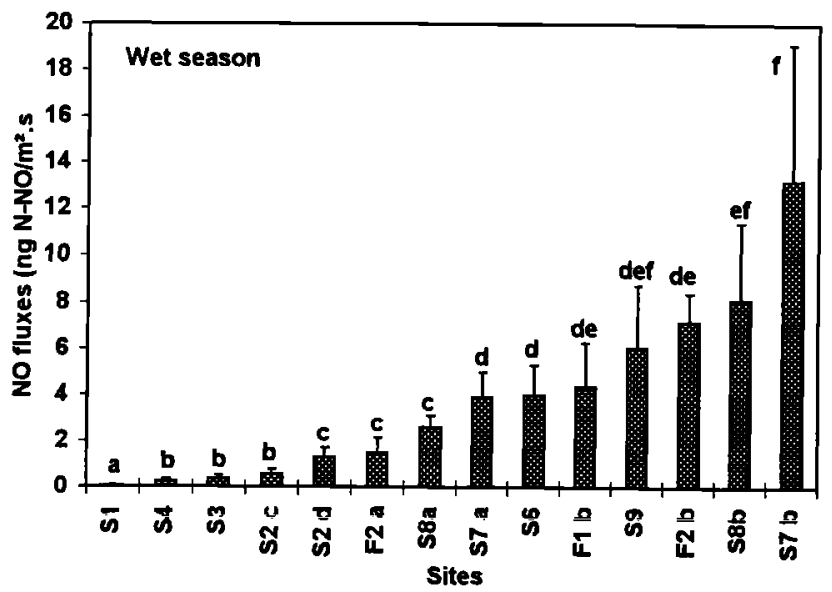

Figure 3. Site effect on NO fluxes during the wet season $(p=0.0001)$. Bars are $95 \%$ confidence limits. Values with the same letter are not significantly different at the $p=0.05$ level. Abbreviations are as follows: $\mathrm{S} 1$, Hyparrhenia savanna; $\mathrm{S} 4$, Loudetia savanna; S3, transition savanna; S2c, Hyparrhenia savanna; S2d, Hyparrhenia savanna termite mounds; F2a, gallery forest; S8a, seasonally wetted grassland (sandy soil, site 1); S7a, fine-leafed savanna; S6, broad-leafed savanna; Flb, rain forest; S9, Guiera savanna; F2b, gallery forest termite mound; $\mathrm{S} 8 \mathrm{~b}$, seasonally wetted grassland (clay soil, site 2 ); and $S 7 \mathrm{~b}$, fine-leafed savanna Acacia patches-settlement site. 


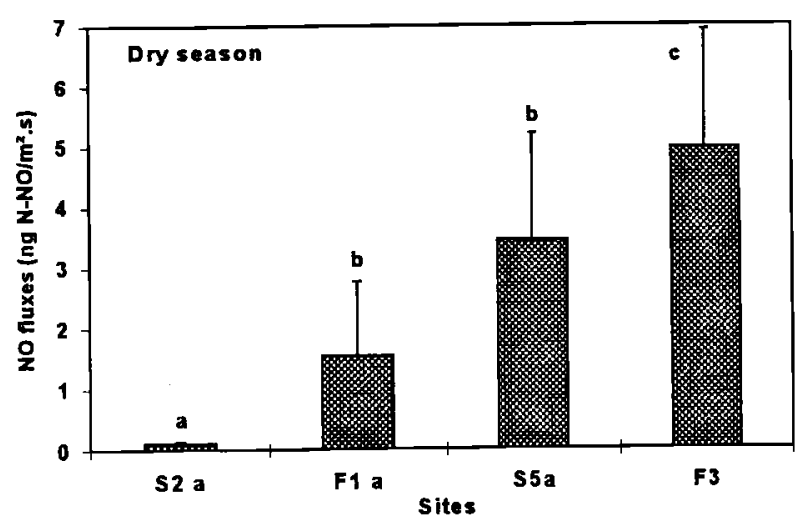

Figure 4. Site effect on NO fluxes during the dry season $(p=0.0001)$. Bars are $95 \%$ confidence limits. Values with the same letter are not significantly different at the $p=0.05$ level, abbreviated as S2a, Hyparrhenia savanna before fire; F1a, rain forest; S5a, Hyperthelia savanna before fire; and F3, secondary forest derived from protected savanna.

significant $(p=0.76)$. This implies that NO flux can be presented simply as the product of site and season effects. In other words, the effect of season is similar on the two plots considered. When compared to the results collected during the dry season, fluxes during the wet season were 3 times higher for the Congo forest (from 1.54 to $4.41 \mathrm{ng} \mathrm{NO} \mathrm{N} \mathrm{m}^{-2} \mathrm{~s}^{-1}$ ) and 5 times higher for the Lamto Hyparrhenia savanna (from 0.11 to $0.56 \mathrm{ng} \mathrm{NO}-\mathrm{N} \mathrm{m}^{-2} \mathrm{~s}^{-1}$ ).

NO fluxes before and after fire occurrence (before the first rainfall) were available for two ecosystems (the Kruger Hyperthelia savanna and the Lamto Hyparrhenia savanna) (figure 6). Effects of site and fire were both significant $(p=$ 0.0001 and $p=0.0006$, respectively). The interaction effect was not significant $(p=0.30)$. Thus NO fluxes are the result of the product of site and fire effect. Fluxes after fire were 3 times higher for the Hyperthelia savanna ecosystem (from 3.03 to $11.32 \mathrm{ng} \mathrm{NO}-\mathrm{N} \mathrm{m}^{-2} \mathrm{~s}^{-1}$ ) and 6 times higher for the Hyparrhenia savanna ecosystem (from 0.11 to $0.65 \mathrm{ng}$ NO-N ${ }^{-2} \mathrm{~s}^{-1}$ ).

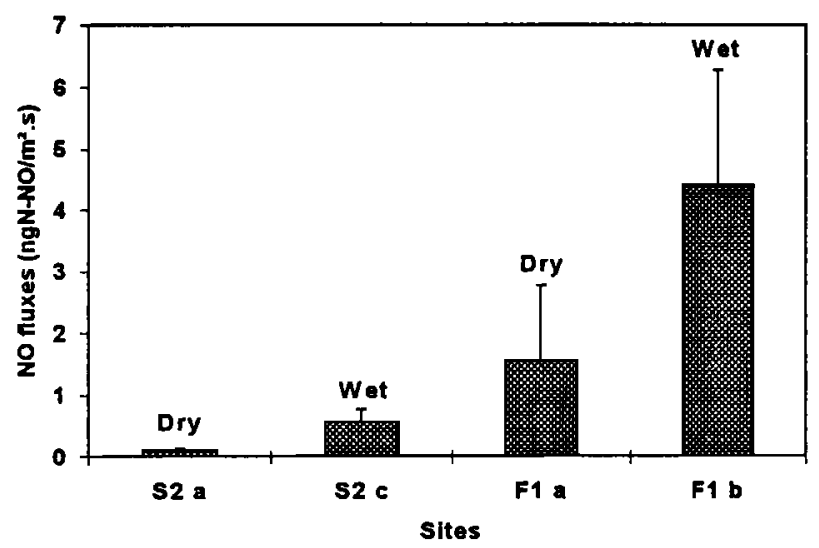

Figure 5. Effect of season on NO fluxes for the Hyparrhenia savanna (S2) and wet evergreen forest (F1). Bars are $95 \%$ confidence limits. Effects of site and season are significant (for both $p=0.0001$ ). Interaction effect is not significant.

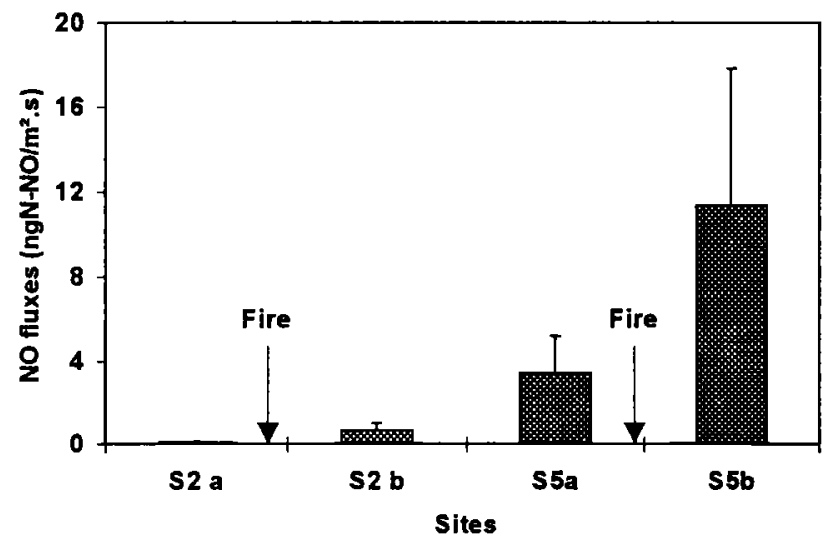

Figure 6. Effect of fire on NO fluxes for the Hyparrhenia savanna (S2) and Hyperthelia savanna (S5). Bars are $95 \%$ confidence limits. Effects of both site and fire are significant $(p$ $=0.0001$ and $p=0.0006$, respectively). Interaction effect is not significant.

\subsection{Effects of Disturbed Sites on NO Emission Rates}

In Lamto, we measured NO emissions on termites mounds present in the Hyparrhenia savanna and in the gallery forest (Table 3). In Nylsvley, we measured NO emissions in undisturbed fine-leafed savanna and in an area disturbed by human habitation (Acacia patches). The three disturbed sites were found to exhibit higher fluxes than the surrounding soil. Effect of disturbance on termite mounds and in Acacia patches was significant (both $p=0.0001$ ). When compared to the results collected on undisturbed sites, fluxes measured on the disturbed site were 2.4 higher $\left(1.32\right.$ vs. $0.56 \mathrm{ng}$ NO-N m $\left.\mathrm{m}^{-2} \mathrm{~s}^{-1}\right)$ for the Lamto Hyparrhenia termite mounds and 5 times higher (7.17 vs. $1.47 \mathrm{ng} \mathrm{NO}-\mathrm{N} \mathrm{m}^{-2} \mathrm{~s}^{-1}$ ) in the Lamto gallery forest termite mounds. The Acacia-dominated soil exhibited a threefold increase in NO emissions when compared to the surrounding soil (13.25 vs. $3.92 \mathrm{ng}$ NO-N m $\mathrm{m}^{-2} \mathrm{~s}^{-1}$, respectively).

\subsection{Variations of NO Fluxes Between Ecosystems: Relationships Between Mean NO Fluxes and Mean Microbial Activities}

Very marked differences among potential microbial activities were observed between the different sites studied (Table 4). Carbon mineralization potential was particularly low in the Niger supersite. Maximum values of carbon mineralization were obtained for the gallery forest ecosystem (Lamto) and for the Acacia patches and the seasonally wetted grassland (site 2). Potential net accumulation of $\mathrm{NH}_{4}^{+}$was high $\left(46 \mu \mathrm{g} \mathrm{NH}{ }_{4}^{+}-\mathrm{N} \mathrm{g}^{-1}\right.$ dry soil in 12 days) only for the gallery forest ecosystem. All the other sites exhibited negative, to low ammonium net accumulation (-11 to $4.8 \mu \mathrm{g} \mathrm{NH}_{4}^{+}-\mathrm{N} \mathrm{g}^{-1}$ dry soil in 12 days). Nitrite accumulation (not shown) was below the detection limit in all sites except in the gallery forest mound soil $(0.51 \mu \mathrm{g}$ $\mathrm{NO}_{3}-\mathrm{N} \mathrm{g}^{-1}$ dry soil in 12 days). Nitrate accumulation was low for the savanna ecosystems of the Lamto Reserve and for the Niger savanna. Disturbed sites like termites mounds and the Acacia patches, along with the seasonally wetted grassland (site 2) and the Hyperthelia savanna of South Africa, showed the 
Table 4. Mean Potential Microbial Activities in Soils Where NO Fluxes Were Measured for Lamto Reserve, Nylsvley Reserve, Kruger Park, and Niger Supersites

\begin{tabular}{|c|c|c|c|c|}
\hline Site & $\begin{array}{c}\text { Carbon Mineralization } \\
\text { Potential }\end{array}$ & $\begin{array}{l}\text { Denitrification } \\
\text { Potential }\end{array}$ & $\begin{array}{c}\mathrm{NO}_{3} \text { net } \\
\text { Potential } \\
\text { Accumulation }\end{array}$ & $\begin{array}{c}\mathrm{NH}_{4}^{+} \text {net } \\
\text { Potential } \\
\text { Accumulation }\end{array}$ \\
\hline \multicolumn{5}{|c|}{ Lamto Reserve Supersite } \\
\hline $\begin{array}{l}\text { S2c, Hyparrhenia savanna } \\
\text { S2d, Hyparrhenia savanna (termite } \\
\text { mounds) }\end{array}$ & $\begin{array}{l}166(5) \\
165(2)\end{array}$ & $\begin{array}{c}\text { UDL } \\
144(4.4)\end{array}$ & $\begin{array}{c}5.2(0.2) \\
22.2(0.3)\end{array}$ & $\begin{array}{l}3.6(0.2) \\
-9.8(0.1)\end{array}$ \\
\hline S3, transition savanna & $148(1)$ & UDL & $-0.7(0.1)$ & $4.8(0.4)$ \\
\hline S4, Loudetia savanna & $164(3)$ & UDL & $-0.5(0.1)$ & $2.1(0.6)$ \\
\hline F2a, gallery forest & $469(16)$ & $327(4.8)$ & $4.4(0.5)$ & $46(0.6)$ \\
\hline F2b, gallery forest (termite mounds) & $361(30)$ & $248(12.2)$ & $58.5(4.7)$ & $-11(0.4)$ \\
\hline \multicolumn{5}{|c|}{ Niger Supersite } \\
\hline \$9, Guiera fallow savanna & $61(4)$ & $23(4.2)$ & $4.1(0.4)$ & $-2.2(0.3)$ \\
\hline \multicolumn{5}{|c|}{ Nylsvley Reserve Supersite } \\
\hline S6, broad-feafed savanna & $182(1)$ & UDL & $13.4(0.75)$ & $-4.1(0.31)$ \\
\hline S7a, fine-leafed savanna & $178(8)$ & UDL & $12.5(0.76)$ & $-4.3(0.02)$ \\
\hline $\begin{array}{l}\text { S7b, fine-leafed savanna } \\
\text { (Acacia patches-settlement site) }\end{array}$ & $511(6)$ & $320(17.6)$ & $35.9(0.62)$ & $-8.1(0.29)$ \\
\hline $\begin{array}{l}\text { S8a, seasonally wetted grassiand } \\
\text { (sandy soil, site 1) }\end{array}$ & $299(7)$ & $207(3.3)$ & $14.1(0.36)$ & $-7.4(0.04)$ \\
\hline S8b, seasonally wetted grassland & $645(15)$ & $1122(44.3)$ & $25.6(0.6)$ & $-6.6(0.1)$ \\
\hline \multicolumn{5}{|c|}{ Kruger Park Supersite } \\
\hline S5a, Hyperthelia savanna & $388(9)$ & UDL & $22.7(0.45)$ & $-3.5(0.82)$ \\
\hline
\end{tabular}

Potential carbon mineralization is expressed as $\mu \mathrm{g}_{\text {of }} \mathrm{C} \mathrm{g}^{-1}$ dry soil in 12 days. Denitrification potential is expressed as $\mathrm{ng} \mathrm{N} \mathrm{g}^{-1}$ dry soil in 4 hours. Potential net accumulations of nitrate and ammonium are expressed as $\mu \mathrm{g} \mathrm{N} \mathrm{g}$ dry soil in 12 days. Values are presented with standard errors in parentheses. UDL stands for under detection limit.

highest $\mathrm{NO}_{3}^{-}$net accumulation. All the other sites in the Nylsvley Reserve exhibited intermediate nitrate net accumulation. Denitrification potential was under the detection limit ( $<1 \mathrm{ng} \mathrm{N}_{2} \mathrm{O}-\mathrm{N} \mathrm{g} \mathrm{g}^{-1}$ dry soil in 4 hours) for the Lamto savanna ecosystems, the broad- and fine-leafed savannas at Nylsvley, and for the Hyperthelia savanna in the Kruger Park. Denitrification potential was low in the Niger savanna (23 ng $\mathrm{N}_{2} \mathrm{O}-\mathrm{N} \mathrm{g}^{-1}$ dry soil in 4 hours) and particularly high in the seasonally wetted grassland (site 2).

Since NO emission rates strongly depend on nutrient cycling processes, and more precisely on nitrification and/or denitrification rates in soils, we analyzed the relationship ieiween îo fiuxes and puitniliai nicroviai activiiies for ine three supersites where data were available (Lamto and Nylsvley. Reserves, and Niger savanna). Mean NO fluxes were not correlated to any potential activities when all the sites were analyzed together (Table 5). When the analysis was restricted to either the Lamto or the Nylsvley supersites, a very strong correlation was observed between NO emission rates and potential net nitrate accumulation. For the Nylsvley supersite, NO fluxes were also strongly correlated with potential total $\mathrm{N}$ accumulation (total $\mathrm{N}=\mathrm{NH}_{4}^{+}-\mathrm{N}+\mathrm{NO}_{3}^{-}-\mathrm{N}$, Table 5). However, the relationship between NO fluxes and potential nitrate net accumulation strongly differed between supersites (Figure 7). For a given nitrate accumulation, NO emission rates were lower at Lamto than at Nylsvley. Particularly high NO fluxes were measured in the Niger savanna despite very low potential nitrate accumulation.

\section{Discussion}

In addition to the large spatial variability commonly observed within a given ecosystem, the marked variability of NO fluxes exhibited between the different ecosystems studied (Figures 3 and 4) illustrates the difficulties in estimating regional NO emissions from chamber measurements alone. However, esimaied ranges can be used for comparaiive purposes. Ine very high variance of NO fluxes within a given supersite and for a given season (Figure 2 ) is primarily linked to the diversity of ecosystems encountered in the supersite and to the occurrence of localized disturbed sites in a given environment. Thus we did not estimate regional NO emissions from our database. Regional emissions are best estimated using models that account for soil moisture, vegetation type, and nitrogen availability. Our chamber-based measurements of NO fluxes are useful to (1) compare mean emission rates between the different sites studied and (2) correlate the variations of mean NO fluxes between ecosystems with the variations of mean potential microbial activities in soils of these ecosystems. 
Table 5. Correlation Coefficients ( $r$ ) Between Mean NO Flux and Mean Potential Microbial Activities for all the Sites of Lamto Reserve, Nylsvley Reserve, and Niger supersites and for Lamto or Nylsvley Supersites Only

\begin{tabular}{lcccccc}
\hline & $\begin{array}{c}\text { Number of } \\
\text { Sites }\end{array}$ & C Mineralization & Denitrification & $\begin{array}{c}\mathrm{NO}_{3}{ }^{-} \mathrm{Net} \\
\text { Accumulation }\end{array}$ & $\begin{array}{c}\mathrm{NH}_{4}{ }^{+} \text {Net } \\
\text { Accumulation }\end{array}$ & $\begin{array}{c}\text { Total Net N } \\
\text { Accumulation }\end{array}$ \\
\hline All Sites & 13 & $\mathrm{NS}$ & $\mathrm{NS}$ & $\mathrm{NS}$ & $\mathrm{NS}$ & $\mathrm{NS}$ \\
Lamto & 6 & $\mathrm{NS}$ & $\mathrm{NS}$ & $0.91^{*}$ & $\mathrm{NS}$ & $\mathrm{NS}$ \\
Nylsvley & 5 & $\mathrm{NS}$ & $\mathrm{NS}$ & $0.97^{*}$ & $\mathrm{NS}$ & $0.99^{\dagger}$ \\
\hline
\end{tabular}

\footnotetext{
NS is nonsignificant at $p=0.05$.

value $p<0.01$

${ }^{\dagger}$ value $p<0.001$.
}

\subsection{Ecosystem Effect on NO Fluxes}

Within a given supersite, NO fluxes strongly depended on the particular ecosystem studied. In the Guinean domain during the wet season, fluxes ranged from 0.28 (Loudetia savanna) to 1.47 ng NO-N m$~^{-2} \mathrm{~s}^{-1}$ (gallery forest) when termite mounds are not included. Similarly, NO emissions ranged from 2.6 (seasonally wetted grassland, site 1) to $8.1 \mathrm{ng} \mathrm{NO}-\mathrm{N} \mathrm{m}^{-2} \mathrm{~s}^{-1}$ (seasonally wetted grassland, site 2) in the Nylsvley Reserve when the Acacia patches are not included. A comparison can be made with NO fluxes reported in the global inventory published by Davidson and Kingerlee [1997]. Reported mean NO emissions

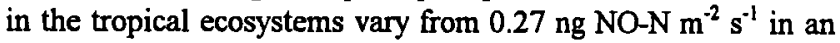
upland pasture during the dry season [Davidson et al., 1991] up to $22 \mathrm{ng} \mathrm{NO}-\mathrm{N} \mathrm{m}^{-2} \mathrm{~s}^{-1}$ in a Namibian savanna [Harris et al., 1996]. High emissions were observed on burned soils (33 ng NO-N m $\mathrm{m}^{-2} \mathrm{~s}^{-1}$, [Neff et al., 1995]), the highest emission ever reported (111 ng NO-N m $\mathrm{s}^{-1}$, [Poth et al., 1995]) being

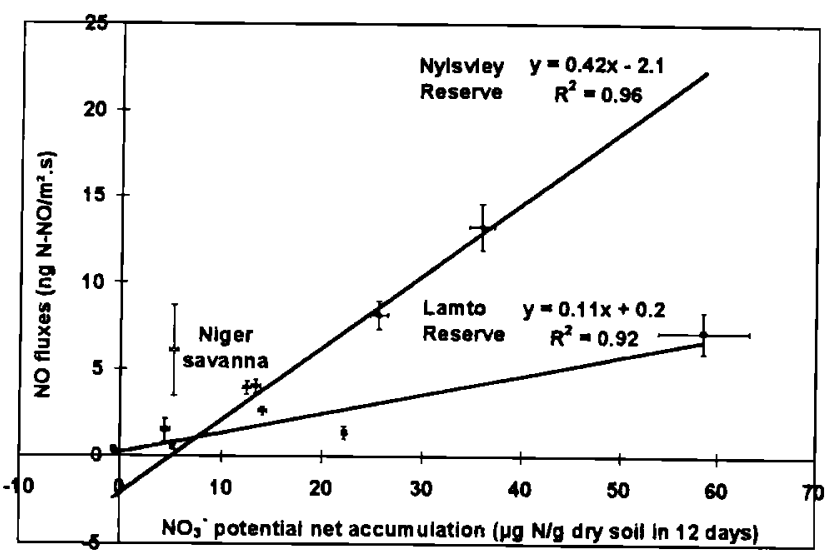

Figure 7. Relationship between the mean NO emission rates observed for different ecosystems during the wet season and the mean potential nitrate net accumulation observed for these ecosystems. Ecosystems from three supersites are presented: Lamto savanna-forest mosaic (squares) (including termite mounds), and Nylsvley Reserve supersite (including seasonally wetted grassland (circles) (site 2) and Acacia patches). For comparison, data are also reported for the Niger supersite (cross). Correlations are significant at $p=0.002$ and $p=0.000 \mathrm{l}$ for Lamto and Nylsvley, respectively. Postfire measurements were made within 2 hours of the fire. observed on burned soil in a postrain fire experiment. With fluxes varying between 0.06 and $13.25 \mathrm{ng} \mathrm{NO}-\mathrm{N} \mathrm{m}^{-2} \mathrm{~s}^{-1}$, the fluxes reported here are in the lower range of already published data.

As anticipated by Matson et al. [1989], our results indicate that assessment of NO emission at the supersite scale (i.e., a few square kilometers) requires a classification of factors including soil/parent material, vegetation, and topography. However, our database shows that these factors alone could not explain the various NO fluxes. In the Nylsvley Reserve, for example, NO fluxes from the two main ecosystems were not statistically different (Figure 3). The two ecosystems have similar soil characteristics, landscape features, and NO fluxes, but very different vegetation types (broad- vs. fine-leafed savannas). Vegetation type is not a key parameter to control NO emission in this case. A contrario, the ecosystem effect on NO fluxes could not be reduced to the distinction between forest and savanna ecosystems, since NO fluxes from the forest sites were not systematically higher than fluxes from the savanna sites (Figures 3 and 4).

Owing to the high spatial variability of NO emission rates exhibited at all scales, the database does not allow for absolute estimates of NO fluxes for a given phytogeographic domain. However, these data showed that NO emissions are low for savanna ecosystems of the Guineo-Congolese/Zambezian regional transitional and Guinean domains. In contrast, higher NO fluxes could be expected for rain forest ecosystems and for savanna ecosystems of the Zambezian and Sahelian domains. Low emissions in the Guineo-Congolese and in the Guinean domains could be related to the type of vegetation growing on site. Indeed, extremely low nitrification rates are reported in the soils of the savannas dominated by Hyparrhenia which may be due to inhibition of nitrifier growth and/or functionality by specific compounds exuded by the roots of the graminea [Munro, 1966]. However, little is known about this aspect, and further investigation is thus warranted. Others factors such as soil/parent material and topography and their interaction with vegetation and NO emissions need to be investigated.

It should be noted that except for the Niger fallow savanna, the ecosystems studied here corresponded to natural ecosystems undisturbed by present human activity. However, the surface area of the zones affected by anthropogenic activities (mainly agriculture) in the tropics is increasing. Thus, in order to provide a more comprehensive view of NO emission from soils in the African tropics, measurements in agroecosystems are warranted. 
In addition, identification of disturbed sites within a given ecosystem is necessary since these sites can exhibit very different emission rates.

\subsection{Effect of Disturbed Sites on NO Fluxes}

The potential role of termites as a source of atmospheric trace gases was suggested by Zimmerman et al. [1982] and Rondon et al. [1993]. At the Lamto Reserve, fluxes were found to be significantly higher on termite mounds than on bulk control soil in forest and savanna ecosystems. Soils on mounds are always associated with nitrogen cycling characterized by low potential ammonium accumulation, relatively high potential nitrate accumulation, and high potential denitrification [Abbadie et al., 1992; Le Roux et al. 1995]. Le Roux et al., [1995] concluded that high NO fluxes on mounds are mostly due to denitrification.

In the Nylsvley Reserve, a similar local effect was found in the Acacia patches. The Acacia dominated soil exhibited a threefold increase in NO emissions when compared to the surrounding soil (13.25 vs. $3.92 \mathrm{ng} \mathrm{NO}-\mathrm{N} \mathrm{m}^{-2} \mathrm{~s}^{-1}$, respectively). Blackmore et al. [1990] showed that the settlers' (Middle Iron Age Tswana people) activities led to levels of $\mathrm{Ca}^{2+}, \mathrm{Mg}^{2+}, \mathrm{K}^{+}$, and $\mathrm{PO}_{4}{ }^{3-}$ in the center of the Acacia patches up to 100 times those in the surrounding savanna soils. The high concentrations of these ions is associated with an increase in $p \mathrm{H}$ and a fivefold increase in organic carbon. This leads to an increase in the water-holding capacity of the soil, from $9 \%$ for surrounding soils to $30 \%$ for the soil under Acacia. The high NO fluxes are most likely linked with the particular status of the soil under the Acacia, that is, the high organic level and the high water-holding capacity that induce favorable conditions for higher primary production and carbon and nitrogen turnover.

Both termite mounds and the Acacia patches are local, disturbed sites or "hot spots" that may be important sources of NO on a regional scale. Furthermore, they support the hypothesis that NO emissions are elevated after disturbances. For instance, termite mounds can cover a large fractional area of Lamto savannas ( $9 \%$ of Hyparrhenia savanna according to Abbadie et al. [1992]). Thus better understanding of the processes controlling NO fluxes from disturbed and undisturbed sites for a given ecosystem is warranted. Both termite mounds and the Acacia patches are the result of a long-term disturbance (biogenic and anthropogenic, respectively). The change associated with this disturbance is considered to be persistent since the sites have reached equilibrium. There is no short-term variation associated with the disturbances so there are no specific short term trends of NO. This is somewhat different from NO emissions enhancement following forest clearing [Keller et al., 1993] with NO emissions responding to changes in vegetation structure and composition.

\subsection{Correlation Between Mean NO Fluxes and Mean Soil Microbial Activities Associated With the Different Ecosystems}

As already mentioned, NO may be produced during nitrification (ammonium oxidation) and during denitrification. In order to improve understanding of NO flux variability between ecosystems, we analyzed the relationship between NO emission rates and soil microbial activity. The best way to do this is to correlate NO fluxes to actual soil microbial activities observed in situ. However, for practical reasons, this approach could not be used to document the processes controlling NO emission in the sites studied here. As a surrogate, potential microbial activities (i.e., obtained on rehumidified soils in optimal conditions) were measured. This prevents any accurate assessment of actual microbial process rates encountered in the field. However, in many cases, some potential activities can help to identify the major processes controlling NO emission rates.

Considering the low nitrification and relatively high denitrification potentials exhibited in the Lamto gallery forest, along with the high soil moisture measured during the wet season, Le Roux et al. [1995] concluded that denitrification was probably the major source of NO in this ecosystem. In contrast, we measured high nitrification and low denitrification in broadand fine-leafed savannas of the Nylsvley Reserve and the Hyperthelia savanna (Kruger Park). Similarly, nutrient-poor savanna ecosystems of Niger are characterized by low denitrification potentials and relatively high nitrate accumulation (Table 4). Thus substantial NO emissions in all these sites were most likely related to nitrification. Very low potentials of both nitrification and denitrification may be partly responsible for the low NO fluxes observed in situ for the three Guinean savannas studied.

The microbial potential measurements did not provide any additional insight into the processes controlling emissions in the following cases: the termite mounds, the Acacia patches, and the seasonally wetted grassland (sites 1 and 2), four sites that exhibited both high nitrification and denitrification potentials. In these cases, soil moisture, aerobic status, and soil carbon content probably played a key role in determining the relative importance of nitrification and denitrification. Indeed, optimal soil moisture is generally about $40-60 \%$ water-filled pore space (WFPS) for nitrification and is greater than $80 \%$ WFPS for denitrification [Davidson, 1993]. For these sites, better understanding of microbial processes controlling NO fluxes in the field requires concurrent measurements of NO fluxes, in situ microbial activities, and soil WFPS. The lack of WFPS data for most of the sites was a major shortcoming, but it was not possible to rectify. However, if desired by other authors, WFPS data could be estimated from water balance modeling exercises. In contrast to nitrification or denitrification potentials, the carbon mineralization potential was not a useful parameter in explaining NO flux variability (Table 5). High fluxes can be associated with relatively low carbon mineralization (Guiera savanna and broad and fine-leafed savanna). Furthermore, carbon mineralization cannot be used to explain the enhancement of emission on termite mounds as they exhibit carbon mineralization rates similar to or lower than values observed for the surrounding soil (Table 4).

A very strong correlation was found between potential $\mathrm{NO}_{3}{ }^{-}$ net accumulation and NO fluxes for the Lamto and Nylsvley supersites (Figure 7). This correlation does not imply that NO emissions are only due to nitrification. For instance, fluxes on termite mounds at Lamto have been shown to be related to denitrification [Le Roux et al., 1995]. Furthermore, the relationships between flux and $\mathrm{NO}_{3}{ }^{-}$potential net accumulation were very different between Lamto and Nylsvley supersites. These relationships show that, although they are not always sufficient to predict the mechanisms involved in NO emissions, 
potential microbial activities could be useful to identify areas where high NO emissions are likely to occur within a given supersite. As suggested by Scholes et al. [1997], complementary studies could be undertaken using ${ }^{15} \mathrm{~N}$. Such experiments allow determination of the substrate used in nitrogen cycling (nitrification-denitrification) and may provide an estimate of potential fluxes based on the turnover rates of the nitrate and ammonium pools. This type of study could be useful when microbial potentials are not conclusive.

\subsection{Seasonal Effects on NO Fluxes}

In both the Lamto savanna and the Congo rain forest ecosystems, fluxes measured during the wet season were significantly higher than fluxes measured during the dry season (Figure 5). Similar results were obtained previously in different tropical ecosystems [Johansson et al., 1988; Davidson et al., 1991]. Emission mechanisms have been studied in both ecosystems.

In the Congo forest, NO emissions were demonstrated to be linked to the chemical decomposition of nitrite (chemodenitrification) [Serça et al., 1994]. Nitrite is produced from ammonium oxidation over the course of the year. Denitrification is also favored by local anaerobic conditions and nitrate input by throughfall during the rainy season which could be an additional source of NO.

At Lamto, both the very low nitrification and denitrification potentials could explain the low NO emission rates measured in all savanna ecosystems. Alternatively, the very low soil moisture $(\approx 5 \%$, corresponding to a $17 \%$ WFPS) measured during the dry season for the $0-5 \mathrm{~cm}$ soil layer could explain the particularly low NO fluxes reported at this time. During the wet season, the WFPS is typically around $65 \%$ in the Hyparrhenia savanna at Lamto [Le Roux et al., 1995]. The observed enhancement of NO emissions with increased soil moisture could be explained by enhancement of both nitrification and denitrification. For both the savanna and forest ecosystems, fluxes were $\approx 4$ times higher during the wet season than during the dry season. Soil moisture plays a key role in controlling NO emission rates. Thus an adequate representation of the spatial-temporal variations of soil moisture status is a prerequisite for reliable and/or predictive estimations of NO emissions, both at large scales or over the longterm [e.g., Yienger and Levy, 1995].

\subsection{Effect of Fire on NO Fluxes}

Fire immediately increased the soil emissions of NO in two savanna ecosystems studied (Figure 6). Similar increases in magnitude have previously been observed on burned sites [Anderson et al., 1988; Johansson et al., 1988; Levine et al., 1988; Rondon et al., 1993]. The influence of fire on NO emissions can be explained by the immediate impact of fire on nitrogen cycling. A number of studies [Covington and Sackett, 1986; Kovacic et al., 1986, Anderson et al. 1988] report an increase in exchangeable ammonium on dry soils after buming. This increase is presumably the result of physicochemical reactions caused by the elevated temperature with the transformation to ammonium of protein-like molecules contained in organic matter and adsorbed on clay [Kovacic et al., 1986; Klopatek et al., 1990]. The nitrogen enrichment in the soil is concomitant with an increase in the nitrification activity [Adedeji, 1983; Menaut et al., 1993]. Both phenomena, separately or together, can enhance NO emissions. Furthermore, it is possible that NO is produced directly as a result of chemical breakdown of organic molecules.

When assessing emission rates from tropical savannas, the marked, short-term effect of fire on NO emissions must be taken into account. African savannas regularly bum (e.g., every I and 5 years for the Lamto and Kruger Park supersites, respectively). The frequency of burning depends on differences in agricultural methods (linked to population density) and conservation policy in the Lamto savanna and in the Kruger Park and the amount of combustible material available. According to Menaut et al. [1991], 5-15\% of the Sahelian savanna , 25-50\% of the Sudanian savanna, and $60-80 \%$ of the Guinean savannas are burned every year. Thus the effect of fire on NO fluxes is expected to have a wide impact in the tropical savanna zone during the dry season at both the ecosystem and regional scales. However, the fire effect reported here seems to be transitory. However, our data are too scarce to document the relative importance of this effect. Its contribution to the annual NO biogenic emission may be of secondary importance. However, it could be an important contributor to episodes of high tropospheric ozone like the pulse effect following the first rains [Scholes et al., 1997].

\section{Conclusion}

No other attempt has been made to compare NO emission rates from such a wide variety of tropical ecosystems using the same methodology. Thus the database presented here constitutes a unique tool to quantify and study NO emission variability from previously unstudied ecosystems in a very understudied continent. This database highlights the importance of linking the variability of NO emissions between different tropical ecosystems to the variability of soil microbial activities exhibited by these ecosystems. Emission rates were low $(<0.6 \mathrm{ng}$ NO-N m $\mathrm{m}^{-2} \mathrm{~s}^{-1}$ ) in Hyparrhenia and Loudetia savannas of the Guinean or Guineo-Congolese domains. Intermediate NO fluxes were obtained in rain forest and gallery forest ecosystems, in seasonally wetted grasslands (site 1) and broad-leafed savannas of the Zambezian domain, and in the dry fallow savanna of the Sahelian domain. Emission rates were highest ( $>7 \mathrm{ng} \mathrm{NO}-\mathrm{N} \mathrm{m}^{-2}$ $\mathrm{s}^{-1}$ ) in a seasonally wetted grassland (site 2) and for disturbed sites (termite mounds and human disturbance). The high variability of NO emissions between ecosystems reported during this study is consistent with similar variability observed during previous studies [e.g., Matson et al., 1990; Ambus and Christensen, 1994]. Note that the NO emissions rates presented here were measured at the ground level. The reabsorption of NO by the canopy would substantially reduce these emissions (up to 40-50\% [Bakwin et al., 1990; Yienger and Levy, 1995; Davidson and Kingerlee, 1997]). The interception of NO and redeposition of $\mathrm{NO}_{2}$ by and onto the vegetation will depend on the type and structure of the canopy. Further work with micrometeorological technologies is required to gain further understanding of this mitigating effect.

Potential microbial activity in some sites was useful for inferring whether NO emissions were related to nitrification or denitrification. Denitrification potentials were very low and could not explain substantial NO fluxes measured in situ for 
broad- and fine-leafed savannas and Hyperthelia savannas of the Zambezian domain and for the Niger savanna. Nitrification is probably the most important process to explain the NO emission observed in these ecosystems. Very low potentials of both nitrification and denitrification explained the low NO fluxes observed in situ for the three Guinean savannas studied, with a possible nitrification inhibition associated with Hyparrhenia [Munro, 1966]. At the landscape scale, the spatial variability of NO fluxes is particularly high when a wide range of ecosystems is encountered, for example in the Lamto and Nylsvley Reserves. However, net nitrate accumulation was found to be a good index for NO flux for these two supersites. In both cases, emissions were higher in soils with higher $\mathrm{NO}_{3}{ }^{-}$net accumulation. However, the slope of the correlation was different between the two cases. Note that no other microbial process indices ( $C$ net mineralization and net $\mathrm{NH}_{4}{ }^{+}$accumulation) or soil characteristics (percentage of $\mathrm{C}$ and $\mathrm{N}, \mathrm{C} / \mathrm{N}$, and $p \mathrm{H}$ ) showed a strong correlation with NO fluxes.

In addition to the variability of NO fluxes exhibited between ecosystems, this database also underlines the marked temporal variability exhibited by NO fluxes due to seasonal and fire effects. Both wet conditions and fire occurrence enhanced NO emissions. We assume that this may be explained by an increase in nutrient availability and modifications of soil properties (moisture and oxygen distribution) which strongly influence bacterial activity.

Combined, the understanding of nitrogen cycling mechanisms, the measurement or simulation of field parameters (particularly soil moisture), and the measurements of NO emissions are necessary to accurately predict the actual range of NO emissions from a given ecosystem and even more from supersites. Thus an accurate classification of ecosystems coupled with a firm understanding of processes controlling emissions is necessary for reliable prediction and spatial extrapolation of biogenic NO emissions.

Acknowledgments. The authors are greatly indebted to E.A. Davidson and to an anonymous reviewer for their helpful comments and valuable suggestions. The authors would like to thank B. Cros, B. Monteny, R.J. Scholes, and $R$. Vuattoux for their invaluable help with logistics during the field campaigns. A special thought is spared in memory of J.L. Tireford. The inhabitants of Koulila Village and the technicians of the Lamto Ecology and Geophysics Stations are also thanked for their efforts on site. We are grateful to C. Jambert and J.P. Lacaux for providing the NO emissions from the Kruger Park. This research was financed by the CAMPUS-DECAFE Programme of the Minister of French Cooperation and by the CNRS. DECAFE Programme. Field experiments in Niger and the Ivory Coast were carried out within the framework of SALT and DECAFE Programme cooperation.

\section{References}

Abbadie, L., M. Lepage, and X. Le Roux, Soil fauna at the forest-savanna boundary: Role of the termite mounds in the nutrient cycling, in Nature and Dynamics of Forest-Savanna Boundaries, edited by J. Proctor, pp. 473-484, Chapman and Hall, New York, 1992.

Adedeji, F.O., Effect of fire on soil microbial activity in Nigerian southem Guinea savanna, Rev. Ecol. Biol. Sol, 20, 483-492, 1983.

Ambus, P., and S. Christensen, Measurements of $\mathrm{N}_{2} \mathrm{O}$ emission from a fertilized grassland: An analysis of spatial variability, J. Geophys. Res., 99, 16549-16555, 1994.

Anderson, I. C., and J.S. Levine, Simultaneous field measurements of biogenic emissions of nitric oxide and nitrous oxide, J. Geophys. Res., 92,965-976, 1987.
Anderson, I. C., J.S. Levine, M.A. Poth, and P. J. Riggan, Enhanced biogenic emissions of nitric oxide and nitrous oxide following surface biomass buming, J. Geophys. Res., 93, 3893-3898, 1988.

Andreae, M.O., Biomass burning: Its history, use, and distribution and its impact on environmental quality and global climate, in Global Biomass Burning, edited by J. S. Levine, pp. 3-21, MIT Press, Cambridge, Mass., 1991.

Anne, P., Sur le dosage rapide du carbone organique des sols. Ann. Agron., $9,161-172,1945$.

Bakwin, P.S., S.C. Wofsy, S.-M. Fan, M. Keller, S.E. Trumbore, and J.M. $\mathrm{Da}$ Costa, Emissions of nitric oxide (NO) from tropical forest soils and exchange of NO between the forest canopy and atmospheric boundary layer, J. Geophys. Res., 95, 16755-16764, 1990.

Blackmer, A.M., and M.C. Cerrato, Soil properties affecting the formation of nitric oxide by chemical reactions of nitrite, Soil Sci. Soc. Am. J., S0, $1215-1220,1986$.

Blackmore, A. C., M.T. Mentis, and R.J. Scholes, The origin and extent of nutrient-enriched patches within a nutrient-poor savanna in South Africa, J. Biogeogr., 17, 463-470, 1990.

Cardenas, L., A. Rondon, C. Johansson, and E. Sanhueza, Effects of the soil moisture, temperature, and $\mathrm{N}$-nutrient in the NO emissions from acidic tropical savannah soils under dry and wet season conditions, $J$. Geophys. Res., 98, 14783-14790, 1993.

Chameides, W.L., and J.C.G. Walker, A photochemical theory of troposphere ozone, J. Geophys. Res., 78, 8751-8760, 1973.

Coetzee, B.J., F. van der Meulen, S. Zwanziger, P. Gonsalves, and P.J. Weisser, A phytosociological classification of the Nylsvley Nature Reserve, Bothalia, 12, 137-160, 1976.

Conrad, $\mathrm{R}$, Flux of $\mathrm{NO}_{\boldsymbol{x}}$ between soil and atmosphere: Importance of soil microbial metabolism, in Denitrification in Soil and Sediment, edited by J. Sorensen and N. P. Revsbech, pp. 105-128, Plenum, New York, 1990.

Covington, W.W., and S.S. Sackett, Effect of burning on soil nitrogen concentrations in ponderosa pine, Soil Sci. Soc. Am. J., 50, 453-457, 1986.

Cros, B., R. Delmas, D. Nganga, B. Clairac, and J. Fontan, Seasonal trends of ozone in equatorial Africa: Experimental evidence of photochemical formation, J. Geophys. Res., 93, 8355-8366, 1988.

Crutzen, P.J., A discussion of the chemistry of some minor constituents in the stratosphere and the troposphere, Pure Appl. Geophys., 1385, 106$108,1973$.

Crutzen, P.J., Atmospheric interactions-homogeneous gas reactions of $\mathrm{C}, \mathrm{N}$, and $\mathrm{S}$ containing compounds, in The Major Biogeochemical Cycles and Their Interactions, edited by B. Bolin and R.B. Cook, SCOPE 21, 67$112,1983$.

Crutzen, P.J., The role of the tropics in atmospheric chemistry, Geophysiology of Amazonia, edited by R.E. Dickinson, pp. 107-132, John Wiley, New York, 1987.

Crutzen, P.J., and M.O. Andreae, Biomass buming in the tropics: Impact on atmospheric chemistry and biogeochemical cycles, Science, 250, 1669$1678,1990$.

Davidson, E.A., Soil water content and the ratio of nitrous oxide to nitric oxide emitted from soil, in The Biogeochemistry of Global Change: Radiatively Active Trace Gases, edited by R.S. Oremland, pp. 369-386, Chapman and Hall, New York, 1993.

Davidson, E.A, and W. Kingerlee, A global inventory of nitric oxide emissionts from süils, Nutr. Cycling Agroecosyst., 48, 37-50, 1997.

Davidson, E.A, and J.P. Schimel, Microbial processes of production and consumption of nitric oxide, nitrous oxide and methane, in Biogenic Trace Gases: Measuring Emissions From Soil and Water, edited by P.A. Matson and R.C. Harriss, pp. 327-357, Blackwell, Cambridge, Mass., 1995

Davidson, E.A., P.M. Vitousek, P.A Matson. R. Riley, G. Garcia-Mendez, and J.M. Maass, Soil emissions of nitric oxide in a seasonally dry tropical forest of Mexico J. Geophys. Res., 96, 15+39-15445, 1991.

Delmas, R.A, and J. Servant, Echanges biosphère-atmosphère d'azote et de soufre en zone intertropicale: Transferts entre les écosystèmes forèt et savane en Afrique de l'Ouest, Atmos. Res., 21, 53-74, 1987.

Delmas, R.A. P. Loudjani, A Podaire, and J.C. Menaut, Biomass burning in Africa: An assessment of annually burnt biomass, in Global Biomass Burning, edited by J.S. Levine, pp. 126-133, MIT Press, Cambridge, 1991.

Delmas, R.A., J.P. Lacaux, J.C. Menaut, L. Abbadie, X. Le Roux, G. Helas, 
and J. Lobert, Nitrogen compound emission from biomass burning in tropical African savanna, FOS/DECAFE 1991 Experiment (Lamto, Ivory Coast), J. Atmos. Chem., 22, 175-193, 1995.

Delmas, R.A. D. Serça, and C. Jambert, Global inventory of $\mathrm{NO}_{\mathrm{x}}$ sources, Nutr. Cycling Agroecosyst., 48, 51-60, 1997.

Firestone, M.K., and E.A Davidson, Microbiological basis of $\mathrm{NO}$ and $\mathrm{N}_{2} \mathrm{O}$ production and consumption, in Exchange of Trace Gases Between Terrestrial Ecosystems and the Atmosphere, edited by M.O. Andreae and D.S. Schimel, pp. 7-21, MIT Press, Cambridge, Mass., 1989.

Fishman, J., S. Solomon, and P.J. Crutzen, Observational and theoretical evidence in support of a significant in-situ photochemical source of tropospheric ozone, Tellus, 3l, 432-446, 1979.

Fishman, J., F.M. Vukovich, and E.V. Browell, The photochemistry of synoptic-scale ozone synthesis: Implications for the global tropospheric ozone budget, J. Atmos. Chem., 3, 299-320, 1985.

Fishman, J., K. Fakhruzzaman, B. Cros, and D. Nganga, Identification of widespread pollution in the southern hemisphere deduced from satellite analyses, Science, 252, 1693-1696, 1991.

Frost, P.G.H, The regional landscape: Nylsvley in perspective, S. Afr. Nat. Sci. Programme Rep., 133, Foundation for research Development Pretoria, 1987.

Galbally, I.E., The emissions of nitrogen to the remote atmosphere: Background paper, in Biogeochemical Cycling of Sulfur and Nitrogen in Remote Areas, edited by J.N. Galloway et al., pp. 27-53, D. Reidel, Norwell, Mass., 1985.

Galbally, I.E., and C.R. Roy, Loss of fixed nitrogen from soils by nitric oxide exhalation, Nature, 275, 734-735, 1978.

Galloway, J.N., and G.E. Likens, Acid precipitation: The importance of nitric acid, Atmos. Environ., 15, 1081-1085, 1981.

Hao, W.M., M.H. Liu, and P.J. Crutzen, Estimates of annual and regional releases of $\mathrm{CO}_{2}$ and others gases to the atmosphere from forest in the tropics, based on the FAO statistics for the period 1975-1980, in Fire in the Tropical Biota: Ecosystem Processes and Global Challenges, edited by J.G. Goldammer, Ecol. Stud. 84, pp. 440-462, 1990.

Harris, G.W., F.G. Wienhold, and T. Zenker, Airborne observations of strong biogenic $\mathrm{NO}_{\mathrm{x}}$ emissions from the Namibian savanna at the end of the dry season, J. Geophys. Res., J01, 23107.23112, 1996.

Higgins, S.I., K.H. Roges, and J. Kemper, A description of the functional vegetation pattern of a semi-arid floodplain, South Africa, Plant Eco., 129, 95-101, 1997.

Johansson, C., Field measurements of emission of nitric oxide from fertilized and unfertilized forest soils in Sweden, J. Atmos. Chem., 1, 429-442, 1984.

Johansson, C., and E. Sanhueza, Emission of NO from savanna soils during the rainy season, $J$. Geophys. Res., 93, 14193-14198, 1988.

Johansson, C., H. Rodhe, and E. Sanhueza, Emission of NO in a tropical savanna and a cloud forest during the dry season, J. Geophys. Res., 93, 7180-7192, 1988.

Kaplan, W.A. S.C. Wofsy, M. Keller, and J.M. Da Costa, Emission of NO and deposition of $\mathrm{O}_{3}$ in a tropical forest system, J. Geophys. Res., 93, 1389-1395, 1988

Keller, M., and W.A. Reiners, Soil-atmosphere exchange of nitrous oxide, nitric oxide, and methane under secondary succession of pasture to forest in the Atlantic lowlands of Costa Rica, Global Biogeochem. Cycles, 8 , 399-409, 1994.

Keller M.W., E. Veldkamp, A.M. Weiltz, and W.A. Reiners, Effect of pasture age on soil trace-gas emissions from a deforested area of Costa Rica, Nature, 365, 244-246, 1993.

Kley, D., J.W. Drummond, M. McFarland, and S.C. Liu, Tropospheric profiles of NO $J$. Geophys. Res., 86, 3153-3161, 1981.

Klopatek, J.M., C. Coe Klopatek, and L.F. DeBano, Potential variation of nitrogen transformations in pinyon-juniper ecosystems resulting from burning, Biol. Fertil. Soils, 10, 35-44, 1990.

Kovacic, D.A. D.M. Swif, J.E. Ellis, and T.E. Hakonson, Immediate effects of prescribed burning on mineral soil nitrogen in ponderosa pine of New Mexico, Soil Sai., 14I, 71-76, 1986.

Lacaux, J.P., J. Loemba-Ndembi, B. Lefeivre, B. Cros, and R. Delmas, Biogenic emissions and biomass burning influences on the chemistry of the fogwater and stratiform precipitations in the African equatorial forest, Atmos. Environ., Part. A, 26, 541-551, 1992.

Lacaux, J.P., H. Cachier, and R. Delmas, Biomass burning in Africa: An overview of its impact on atmospheric chemistry, in Fire in the
Environment: The Ecological, Atmospheric, and Climatic Importance of Vegetation Fires, edited by P.J. Crutzen and J.G Goldammer, pp. 159-191, John Wiley, New York, 1993.

Le Roux, X., L. Abbadie, R. Lensi, and D. Serça, Emission of nitrogen monoxide from African tropical ecosystems: Control of emission by soil characteristics in humid and dry savannas of West Africa, J. Geophys. Res., 100, 23133-23142, 1995.

Levine, J.S., W.R. Cofer III, and D.I. Sebacher, The effects of fire on biogenic soil emissions of nitric oxide and nitrous oxide, Global Biogeochem. Cycles, 2, 445-449, 1988.

Levine, J.S., E.L. Winstead, D.A.B. Parsons, M.C. Scholes, R.J. Scholes, W.R. Cofer III, D.R. Cahoon Jr., and D. I. Sebacher, Biogenic soil emissions of nitric oxide (NO) and nitrous oxide $\left(\mathrm{N}_{2} \mathrm{O}\right)$ from savannas in South Africa: The impact of wetting and buming, J. Geophys. Res., 101, 23689-23697, 1996.

Lipschultz, F., O.C. Zafiriou, S.C. Wofsy, M.B. Mc Elroy, F.W. Valois, and S.W. Watson, Production of $\mathrm{NO}$ and $\mathrm{N}_{2} \mathrm{O}$ by soil nitrifying bacteria, Nature, 294, 641-643, 1981.

Liu, S.C., M. Trainer, F.C. Fehsenfeld, D.D. Parrish, E.J. Williams, D.W, Fahey, G. Hübler, and P.C. Murphy, Ozone production in the rural troposphere and the implications for regional and global ozone distributions, J. Geophys. Res., 92, 4191-4207, 1987.

Livingston, G.P., and G.L. Hutchinson, Enclosure-based measurement of trace gas exchange: Applications and sources of error, in Biogenic Trace Gases: Measuring Emissions From Soil and Water, edited by P.A. Matson and R.C. Harriss, pp. 14-51, Blackwell Sci., Cambridge, Mass., 1995.

Logan, J.A., Nitrogen oxides in the troposphere: Global and regional budgets, J. Geophys. Res., 88, 10785-10807, 1983.

Logan, J.A., M.J. Prather, S.C. Wofsy, and M.B. Mc Elroy, Tropospheric chemistry: A global perspective, J. Geophys. Res., 86, 7210-7254, 1981.

Makany, L., Végétation des Plateaus Teke (Congo), Collection travaux de l'université de Brazzaville, pp. 1-301, Univ. Brazzaville, Brazzaville, Congo, 1976.

Martin, R, M.C. Scholes, A Mosier, D. Ojima, E.A. Holland, and W.J. Parton, Controls on annual emissions of nitric oxide from soils of the Colorado shortgrass steppe, Global Biogeochem. Cycles, 12, 81-91, 1998.

Matson, P.A, P.M. Vitousek, and D.S. Schimel, Regional extrapolation of trace gas flux based on soils and ecosystems, in Exchange of Trace Gases Between Terrestrial Ecosystems and the Atmosphere, edited by M.O. Andreae and D.S. Schimel, pp. 97-108, MIT Press, Cambridge, Mass., 1989.

Matson, P.A, P.M. Vitousek, G.P. Livingston, and N.A Swanberg, Sources of variation in nitrous oxide flux from amazonian ecosystems, $J$. Geophys. Res., 95, 16789-16798, 1990.

Mc Elroy, M.B., and S.C. Wofsy, Tropical forests: Interactions with the atmosphere, in AAAS Symposium Volume: Tropical Forests and World Atmosphere, edited by G.T. Prance, pp. 33-60, Westview, Boulder, Colo., 1986.

Meixner, F.X., T. Fickinger, L. Marufu, D. Serça, F.J. Nathaus, E. Makina, L. Mukurumbira, and M.O. Andreae, Preliminary results on nitric oxide emission from a southern African savanna ecosystem, Nutr. Cycling Agroecosyst., 48, 123-138, 1997.

Menaut, J.C., The vegetation of African savannas, in Tropical Savannas, edited by F. Bourlière, pp. 109-149, Elsevier, New York, 1983.

Menaut, J.C., F. Lavenu, P. Loudjani, and A. Podaire, Biomass burning in West African savannas, in Global Biomass Burning, edited by J.S. Levine, pp. 133-143, MIT Press, Cambridge, Mass., 1991.

Menaut, J.C., L. Abbadie, and P.M. Vitousek, nutrient and organic matter dynamics in tropical ecosystems, in Fire in the Environment: The Ecological, Atmospheric, and Climatic Importance of Vegetation Fires, edited by P.J. Crutzen and J.G Goldammer, pp. 219-230, John Wiley, New York, 1993.

Munro, P.E., Inhibition of nitrifiers by grass root extracts, J. Appl. Ecol., 3, $231-238,1966$.

Neff, J.C., M. Keller, E.A. Holland, A.W. Weitz, and E. Veldkamp, Fluxes of nitric oxide from soils following the clearing and burning of a secondary tropical rain forest, J. Geophys. Res., 100, 25913-25922, 1995.

Noxon, J.F., NO in the mid-Pacific troposphere, Geophys. Res. Lett., 8, 1223-1226, 1981. 
Noxon, J.F., $\mathrm{NO}_{3}{ }^{-}$and $\mathrm{NO}_{2}$ in the mid-Pacific troposphere, J. Geophys. Res., 88, 11017-11021, 1983.

Parsons, D.A.B., M.C. Scholes, R.J. Scholes, and J.S. Levine, Biogenic NO emissions from savanna soils as a function of fire regime, soil type, soil nitrogen, and water status, J. Geophys. Res., JOI, 23684-23688, 1996.

Poth, M., I.C. Anderson, H.S. Miranda, A.C. Miranda, and P.J. Riggan, The magnitude and persistence of soil $\mathrm{NO}, \mathrm{N}_{2} \mathrm{O}, \mathrm{CH}_{4}$, and $\mathrm{CO}_{2}$ fluxes from burned tropical savanna in Brazil, Global Biogeochem. Cycles, 9, 503$513,1995$.

Rondon, A., C. Johansson, and E. Sanhueza, Emission of nitric oxide from soils and termite nest in a Trachypogon savanna of the Orinoco basin, $J$. Atmos. Chem., 17, 293-306, 1993.

Sanhueza, E., W.M. Hao, D. Scharffe, L. Donoso, and P.J. Crutzen, $\mathrm{N}_{2} \mathrm{O}$ and NO emissions from soils of the northern part of the Guyana Shield, Venezuela, J. Geophys. Res., 95, 22481-22488, 1990.

Schimel, D.S., S. Simkins, T. Rosswall, A.R. Mosier, and W.J. Parton, Scale and the measurement of nitrogen fluxes from terrestrial ecosystems, in Scales and Global Change, edited by T. Rosswall, R.G. Woodmansce, and P.G. Risser, pp. 179-193, John Wiley, New York, 1988.

Scholes, M.C., R. Martin, R.J. Scholes, D. Parsons, and E. Winstead, NO and $\mathrm{N}_{2} \mathrm{O}$ emissions from savanna soils following the first simulated rains of the season, Nutr. Cycling Agroecosyst., 48, 115-122, 1997.

Seiler, W., and P.J. Crutzen, Estimate of gross and net flux of carbon between the biosphere and the atmosphere from biomass burning, Clim. Change, 2, 207-247, 1980.

Serça, D., R. Delmas, C. Jambert, and L. Labroue, Emissions of nitrogen oxides from equatorial rain forest in central Africa: Origin and regulation of NO emission from soils, Tellus, Ser. B, 46, 143-254, 1994.

Slemr, F., and W. Seiler, Field measurement of $\mathrm{NO}$ and $\mathrm{NO}_{2}$ emissions from fertilized and unfertilized soils, J. Atmos. Chem., 2, 1-24, 1984.

Thomton, F.C., P.A. Pier, and R.J. Valente, NO emissions from soils in the southeastern United States, J. Geophys. Res., 102, 21189-21195, 1997.

Tiedje, J., Denitrification, in Methods of Soil analysis, , edited by A Page et al., pp. 1011-1026, Am. Soc. Agron., Madison, Wis., 1982.

Van Cleemput, $O$., and L. Baert, Nitrite: A key compound in N-loss processes under acid conditions, Plant Soil, 76, 233-241, 1984.

Veldkamp, E., and M. Keller, Nitrogen oxide emissions from a banana plantation in the humid tropics, J. Geophys. Res., 102, 15889-15898, 1997.
Werger, M.J.A, and B.J. Coetzee, Biogeographical division of southern Africa, in Biogeography and Ecology of Southern Africa, edited by M.J.A. Werger, pp. 301-462, Dr. W. Junk, Norwell, Mass., 1978.

Williams, E.J., and E.A. Davidson, An intercomparison of two chamber methods for the determination of emission of nitric oxide from soil, Atmos. Environ., Part. A, 27, 2107-2113, 1993.

Williams, E.J., D.D. Parrish, M.P. Burr, F.C. Fehsenfeld, and R. Fall, Measurement of soil NO emission in central Pennsylvania, J. Geophys. Res., 93, 9539-9546, 1988.

Yienger, J.J., and H. Levy II, Empirical model of global soil-biogenic NO emissions, J. Geophys. Res., IOO, 11447-11464, 1995.

Zimmerman, P.R., J.P. Greenberg, S.O. Wandiga, and P.J. Crutzen, Termites: A potentially large source of atmospheric methane, carbon dioxide, and molecular hydrogen. Science, 218, 563-565, 1982.

L Abbadie and $\mathrm{O}$. Ronce, Laboratoire d'Ecologie ENS, URA CNRS 258, 46 rue d'Ulm, 75005 Paris, France

D. Serça, R. Delmas, Laboratoire d'Aérologie, UMR CNRS/UPS 5560, 14 avenue Edouard Belin, 31400 Toulouse Cedex, France. (e-mail: serd@aero.obs-mip.fr; delr@aero.obs-mip.fr)

L. Labroue, Centre d'Ecologie des Systèmes Aquatiques Continentaux, UMR CNRS/UPS C5576, Toulouse, France

R. Lensi, Laboratoire d'Ecologie Microbienne des Sols, UMR CNRS 5557, 43 bd du 11 novembre 1918, 69622, Villeurbanne, France (email: lensi@univ-lyonl.fr)

$X$. Le Roux, Unité Associée Bioclimatologie-PIAF, Domaine de Crouelle, F 63069, Clermont-Ferrand Cedex 02, France (email: xleroux@clermont.inra.fr)

D.A.B. Parsons, Division of Forest Science Technology, CSIR, Private Bag 395, Pretoria 0001, South Africa (email: dparsons@forestek.csir.co.za) M.C. Scholes, Department of Botany, University of the Witswatersrand, Johannesburg, South Africa (email: mary@gecko.biol..wits.ac.za)

(Received November 14, 1997; revised July 27, 1998; accepted August 21, 1998.) 